\title{
Article \\ Effects of Garden Amendments on Soil Available Lead and Plant Uptake in a Contaminated Calcareous Soil
}

\author{
Tara Geiger ${ }^{1}$ (D) and Urszula Norton ${ }^{1,2, *(D)}$ \\ 1 Department of Plant Sciences, University of Wyoming, 1000 E. University Ave., \\ Laramie, WY 82071-3354, USA; tarageiger@gmail.com \\ 2 Program in Ecology, University of Wyoming, 1000 E. University Ave., Laramie, WY 82071-3354, USA \\ * Correspondence: unorton@uwyo.edu
}

Citation: Geiger, T.; Norton, U.

Effects of Garden Amendments on Soil Available Lead and Plant Uptake in a Contaminated Calcareous Soil. Appl. Sci. 2021, 11, 5777. https:// doi.org/10.3390/app11135777

Academic Editor: Agnieszka

Medyńska-Juraszek

Received: 1 June 2021

Accepted: 19 June 2021

Published: 22 June 2021

Publisher's Note: MDPI stays neutral with regard to jurisdictional claims in published maps and institutional affiliations.

Copyright: (c) 2021 by the authors. Licensee MDPI, Basel, Switzerland. This article is an open access article distributed under the terms and conditions of the Creative Commons Attribution (CC BY) license (https:// creativecommons.org/licenses/by/ $4.0 /)$.

\begin{abstract}
Gardeners use organic and inorganic substances to enhance plant growth, which can inadvertently impact soil solubility and plant uptake of unknown contaminants. Consequently, human exposure can increase through gardening and consumption of produce grown in potentially contaminated soils. A greenhouse experiment was established to examine the effects of biochar, compost, and common inorganic fertilizer on soil lead $(\mathrm{Pb})$ availability for radish (Raphanus sativus, L.) and lettuce (Lactuca sativa, L.) grown in a calcareous soil containing excessively high lead (Pb), along with $\mathrm{Pb}$ accumulation in radish tissue. Results indicate that soil amended with biochar and planted to radish saw an $18 \%$ reduction in available $\mathrm{Pb}$ and an $11 \%$ decrease in plant tissue content when compared to the control. Compost showed an $8 \%$ reduction in available $\mathrm{Pb}$, but a $19 \%$ increase in tissue content. In contrast, soil with inorganic fertilizer planted to radish increased in both soil $\mathrm{Pb}$ availability by $11 \%$ and $\mathrm{Pb}$ tissue content by $40 \%$. Adding water-soluble inorganic fertilizers to contaminated calcareous soils without added organic matter enhances soil $\mathrm{Pb}$ availability and often asymptomatic plant $\mathrm{Pb}$ bioaccumulation. In conclusion, gardeners are encouraged to test their soils for contamination and apply biochar in combination with compost, as this combination is recommended to improve soil health and aid in overcoming initial $\mathrm{N}$ deficiencies induced by biochar.
\end{abstract}

Keywords: biochar; compost; inorganic fertilizer; heavy metal; trace element; $\mathrm{Pb}$ bioconcentration factor; $\mathrm{Pb}$ translocation factor

\section{Introduction}

Urban gardening has historically been an intricate part of the global food supply, including in the United States (U.S.). As an example, urban gardening was promoted by the U.S. government during the Great Depression and both World Wars as means to reduce food shortages $[1,2]$. More recently, urban population growth coupled with economic and political changes have increasingly undermined urban food distribution networks and created food deserts, thus inspiring a renewed interest in urban gardening [3].

Gardening as an activity plays an important role in alleviating many issues that are amplified by social isolation (COVID-19 restrictions, for example), or are often driven by economic instability. Research suggests a variety of benefits for both individuals and the community, including: (1) reduced carbon (C) "food-print" [4]; (2) health benefits from increased physical activity [1,2,5]; (3) improved psychological and social well-being [1,5,6]; and (4) improved nutrition [3], food security [1,3], and access to fresh food [1]. It can be especially beneficial to community-building and connectivity in loose-knit urban environments by facilitating improved networks and organizational capacity in lower income and minority neighborhoods $[1,6]$.

However, the benefits of urban gardening should be balanced with potential risks of exposure to contaminants, such as heavy metals like lead $(\mathrm{Pb})$. Heavy metals do not decompose biologically or chemically, but instead accumulate over time in the soil matrix and soil organisms where they can persist indefinitely, posing a risk to human health $[7,8]$. 
Though heavy metals exist naturally in the environment, their concentrations are often elevated in urban areas. For example, $\mathrm{Pb}$ occurs naturally in the Earth's crust at concentrations below $50 \mathrm{mg} \mathrm{kg}^{-1}$ [9], but concentrations of $\mathrm{Pb}$ in urban soils can reach $150 \mathrm{mg} \mathrm{kg}^{-1}$ or greater, with some soils having total $\mathrm{Pb}$ concentrations in excess of $1000 \mathrm{mg} \mathrm{kg}^{-1}[3,10]$.

The main sources of heavy metals in urban soils are atmospheric fallout from coal and fuel combustion, vehicle emissions, mining activities, fertilizer use, municipal solid waste disposal, and industrial waste [11-14]. Lead specifically was historically used in Pb-based paints, leaded gasoline, and pest and weed control chemicals. Although the threat posed by $\mathrm{Pb}$-based paint, which was common in the U.S. until 1978, is generally well-known, research on urban gardeners suggests a low level of awareness of soil pollutants [15]. For example, a survey of 121 urban farmers and gardeners from Kansas, Missouri, and Washington states, found that over $80 \%$ were interested in learning more about soil contamination and testing in urban areas [16].

Lead primarily accumulates in the surface layer of urban soils [9]. It exists as a free metal ion-the most available form for plants-in the soil solution and can also complex with organic and inorganic soil constituents, like humic acid and carbonate $\left(\mathrm{CO}_{3}{ }^{2-}\right)$, respectively [9]. Unlike some heavy metals (cadmium, for instance), which have high water solubility and mobility in soil due to weak sorption to organic matter $[17,18], \mathrm{Pb}$ has a high affinity for particle surfaces [9]. As a result, it strongly binds to organic and colloidal materials, limiting its solubility [9]. For this reason, only a small amount of the total $\mathrm{Pb}$ present in soil is available for plant uptake [9].

Exposure to $\mathrm{Pb}$, which has no known biological function in animals or plants [9], occurs via inhalation, dermal contact, and ingestion, typically through food crops grown in contaminated soils [3,19-21]. Plants sometimes accumulate heavy metals in concentrations that are detrimental to humans before phytotoxic effects are visible [22]. Even low-level exposure to $\mathrm{Pb}$ is associated with many adverse effects in humans, especially in children, who are particularly at risk due to increased direct contact with soils and associated hand-to-mouth play $[3,23]$. These include neurological disorders, such as depression and schizophrenia, the effects of which are particularly concerning in children because they can impair learning and memory, affect behavior and mood, and alter neuromotor and neurosensory functions [23].

Lead is also known to impair plant growth, root elongation, seed germination, seedling development, transpiration, chlorophyll production, lamellar organization in the chloroplast, and cell division [9]. In a study on the effects of two different $\mathrm{Pb}$ concentrations (0.1 and $0.5 \mathrm{mM}$ ) on radish (Raphanus sativus, L.), Gopal et al. (2008) observed a 30-50\% reduction in dry weight compared with the control, along with decreased chlorophyll concentrations [24]. However, the impact of $\mathrm{Pb}$ on plants varies by species and depends on several factors, including $\mathrm{Pb}$ concentration, duration of exposure, and stage of plant development [9]. For most species, the majority of absorbed lead (approximately $95 \%$ or more) is accumulated in the roots [9]. Some plants, specifically expanded hypocotyl root vegetables, are more likely to accumulate $\mathrm{Pb}$ in their core [3]. These include popular root vegetables among gardeners, like Daucus carota, L. (carrot), Brassica rapa, L. (turnip), Beta vulgaris, L. (beets), and radish [3].

Evidence also suggests that heavy metals have serious adverse effects on soil health through changes in microbiota populations and community structures, and can inhibit important microbial metabolic processes like respiration, denitrification, and enzymatic activity [25]. Moreover, heavy metals can negatively impact soil physicochemical properties, including soil organic $C$ sequestration and degradation $[7,26]$. Lead contaminated soils are often associated with low soil organic matter $(\mathrm{OM})$; low soil fertility, including nitrogen $(\mathrm{N})$ and phosphorous $(\mathrm{P})$ availability; and micronutrient imbalances [27].

Gardeners apply a variety of substances (hereinafter "amendments") to their gardens to improve vegetable production, stabilize $\mathrm{pH}$, and to condition the soil. These amendments effect the physicochemical properties of the soil in different ways, which can, in turn, influence $\mathrm{Pb}$ availability in soil, along with plant uptake [28,29]. Soil $\mathrm{pH}$, for example, 
is one of the most important factors determining heavy metal availability in soil [30,31]. In general, for cationic metal species like $\mathrm{Pb}^{+2}$, a higher $\mathrm{pH}$ results in decreased availability, while anions (e.g., arsenic $\left(\mathrm{As}^{-3}\right)$ ) become more available [19]. Organic matter $(\mathrm{OM})$ content is also a significant factor influencing the availability of heavy metals and can reduce the mobility of many heavy metals through sorption to surfaces, along with precipitation and complexation reactions [7]. Other important soil factors affecting heavy metal availability include: (1) clay content, and thus cation exchange capacity (CEC), as clays are negatively charged [19]; (2) time, which results in heavy metals gradually shifting into less-accessible soil pools as they move into clay interlayer regions and form innersphere surface complexes with clay lattices [19,32]; (3) soil texture, wherein coarse-textured soils (greater sand content) are expected to have greater availability than fine-textured soils (greater clay content) [19]; (4) amount of heavy metal(s) present [33]; (5) metal ion speciation and, in particular, the concentration of free metal ions present [34,35]; and (6) soil oxidation-reduction (redox) potential, particularly in flooded soils $[19,36]$.

Biochar is a carbon-rich organic material produced through pyrolysis of straw, manure, wood, and other agricultural wastes under a limited or no-oxygen environment $[37,38]$. Interest in biochar has grown significantly in recent years as demand increases for low-cost, environmentally-friendly technologies to address soil and water contamination, and to increase soil health. Used in a variety of applications, research shows that biochar can play an important role in increasing soil C sequestration [39], reducing $\mathrm{NO}_{2}$ emissions [40], and can decrease fertilizer needs and nutrient leaching [41]. It also has significant capacity for adsorption of both organic and inorganic compounds, including heavy metals [7,42]. A recent meta-analysis of 74 scientific papers found that amendment with biochar resulted in overall decreases in soil bioavailable metal concentrations of $\mathrm{Cd}, \mathrm{Pb}$, and $\mathrm{Cu}$ by $52 \%$, $46 \%$, and $29 \%$, respectively, and reductions in the average concentrations in plant tissues by $38 \%, 39 \%$, and $25 \%$ [43].

Persisting in soil for centuries [39], biochar is highly recalcitrant due to its stable, aromatic structure [44] and has a large surface area and porosity $[43,45]$. The total surface area correlates with sorption and retention of both nutrients and contaminants, while pore volume affects water availability and soil aeration [46]. Oxygen-containing functional groups, especially carboxyl groups, on biochar's surface result in a net negative charge, increasing soil cation exchange capacity (CEC) and adsorption capacity $[7,42]$.

Pyrolysis temperature is one of the most important factors influencing the molecular structure, nutrient composition, and physicochemical properties of biochar [46,47]. In general, surface area increases at greater pyrolysis temperatures [46,47], as does pore volume [46]. Higher pyrolysis temperatures also produce greater ash and carbon content and a higher $\mathrm{pH}[46,47]$, but lower $\mathrm{N}$ content [47]. The nutrient composition of biochar is also strongly influenced by its feedstock source [46]. A meta-data analysis of over 5400 peer-reviewed journal articles suggests that the greatest total $\mathrm{N}$ content, along with total $\mathrm{P}, \mathrm{K}, \mathrm{Ca}$, and $\mathrm{Mg}$, are found in biochar produced from manures/biosolids, whereas wood biochar typically has the lowest concentrations [46].

Compost, a relatively popular soil amendment among urban gardeners, consists of both readily decomposable materials and humic substances derived from raw organic materials, such as manure and plant biomass. Like biochar, negatively charged functional groups on its surface can help limit heavy metal availability [48]. Further, compost is rich in humic substances, which are responsible for many complex chemical reactions in soil due to their ability to interact with metal ions, minerals, oxides, hydroxides, and organic contaminants to form water-soluble and water-insoluble complexes [8,19,48]. Evidence suggests that humic substances like humic and fulvic acids enhance plant growth and stimulate nutrient uptake [49]. Compost has also been shown to reduce the available portion of heavy metals in both soil and plant tissue [50-52]. For instance, one study on the influence of green waste compost applied at $2 \%, 5 \%$, and $10 \%(w / w)$ to soils spiked with $500 \mathrm{mg} \mathrm{kg}^{-1}$ of lead nitrate showed a reduction of up to 1.6-fold in Pb uptake by pak choi cabbage (Brassica campestris, L.) as compared to the control soil [53]. The same study also 
found that the concentration of available $\mathrm{Pb}$ in soil decreased by $35 \%$ in comparison to a control when compost was applied at a rate of $10 \%(w / w)$.

Many gardeners also augment their soil nutrient status through application of inorganic fertilizers. Studies on inorganic fertilizers present mixed findings with respect to changes in soil properties and effect on heavy metal availability, likely due to the wide range of chemical forms and nutrient ratios, effects on soil $\mathrm{pH}$, and because heavy metals interact differently with different nutrients [54]. It is generally suggested that $\mathrm{Pb}$ mobility is increased by inorganic fertilizers containing ammonium $\left(\mathrm{NH}_{4}\right)$, while phosphates have been found to increase the negative charge of soil, which in turn enhances heavy metal sorption, decreasing $\mathrm{Pb}$ availability $[55,56]$. In contrast, He et al. (2018) suggest that $\mathrm{K}$ may exchange with $\mathrm{Pb}$ ions on soil surfaces, increasing $\mathrm{Pb}$ availability [57].

Gardening is a popular local practice in Laramie, the fourth largest town in Wyoming [58]. The region is characterized by very low temperatures (average of $4.4^{\circ} \mathrm{C}$ ) and precipitation (<300 mm annually), along with a typical growing season of only 85 to 115 days. Nevertheless, Albany County, where Laramie is situated, has over 450 farms, resulting in over 6.3 million dollars in crop sales annually [59]. Residents of Laramie commonly use hoop and greenhouses to extend the growing season, particularly for specialty and warm-season crops, along with managed irrigation. The city is also home to several smallholder farms that sell produce through the farmers market and offer community-supported agriculture (CSA) programs to residents.

Exposure to $\mathrm{Pb}$, especially over time, causes serious injury to both humans and the environment, including impaired crop performance and damage to overall soil health. Gardeners in Laramie and other urban areas may be unaware of the risks for exposure through vegetable production in their yards, community gardens, and other cultivatable city spaces like alleys, as well as the influence of common amendments on $\mathrm{Pb}$ availability in soil. It is therefore imperative to investigate and educate gardeners on effective, economical technologies that are widely available, and which can reduce transfer of $\mathrm{Pb}$ from soil to crops while also addressing damage to soil function caused by heavy metals like $\mathrm{Pb}$. The main objective of this study was to quantify the effects of three locally-produced soil amendments on the physicochemical properties and $\mathrm{Pb}$ availability of a native calcareous soil, as well as assess their impact on plant uptake.

\section{Materials and Methods}

\subsection{Site Description}

The study was conducted in Laramie, Wyoming $\left(41.31^{\circ} \mathrm{N}\right.$ LAT, $105.59^{\circ} \mathrm{W}$ LONG, $2214 \mathrm{~m}$ above sea level elevation). The area has a semi-arid climate, with an average annual precipitation of $286 \mathrm{~mm}$ [60]. The average temperature for the area is $4.4{ }^{\circ} \mathrm{C}$, with a temperature maximum of $12.4^{\circ} \mathrm{C}$ and minimum of $-3.7^{\circ} \mathrm{C}$ [60]. Laramie experiences strong winds, with an average daily wind speed of $19.3 \mathrm{~km} \mathrm{~h}^{-1}$ and a maximum daily average wind speed of $53 \mathrm{~km} \mathrm{~h}^{-1}$ [60]. Soils are predominantly sandy clay loams and classified as fine-loamy, mixed, superactive, frigid Ustic Haplargids developed from a mixture of slope wash materials from limestone and red sandstone [61].

Soil samples (0-10 cm depth) were collected from an area approximately $20 \mathrm{~m}$ away from a World War II-era factory built by the federal government to process aluminumbearing ore and later converted to a gravel aggregate production facility [62]. The factory was operational until 1985, when it was used to recover arsenic acid from smokestack sludge and flue dust, both byproducts of power plants [62]. These byproducts were stockpiled outside the facility until processing and resulted in highly elevated concentrations of both soil and water contaminants [63]. Laboratory tests conducted showed moderately alkaline $\mathrm{pH}$, low $\mathrm{OM}$, low electrical conductivity (EC), low concentrations of available phosphorous (P), inorganic nitrogen (INN), and elevated total $\mathrm{Pb}$ concentrations (Table 1). 
Table 1. Characteristics of native soil collected at beginning of pre-incubation. Data presented as average values with standard error in parentheses $(n=3)$.

\begin{tabular}{|c|c|}
\hline Soil Metrics & Soil Measurement \\
\hline Texture & Sandy Clay Loam \\
\hline Moisture $\left(\mathrm{g} \mathrm{g}^{-1}\right)$ & $0.04(0.01)$ \\
\hline pH (1:2 soil: water) & $7.4(0.1)$ \\
\hline $\mathrm{EC}\left(\mu \mathrm{S} \mathrm{cm} \mathrm{cm}^{-1}\right)$ & $553(3)$ \\
\hline Total Organic Carbon (TOC) $\left(\mathrm{mg} \mathrm{kg}^{-1}\right)$ & $36,793(1638)$ \\
\hline Inorganic Carbon (IC) $\left(\mathrm{mg} \mathrm{kg}^{-1}\right)$ & $17,573(248)$ \\
\hline Total Nitrogen $\left(\mathrm{mg} \mathrm{kg}^{-1}\right)$ & $2123(15)$ \\
\hline Inorganic Nitrogen (INN) $\left(\mathrm{mg} \mathrm{kg}^{-1}\right)$ & $9.90(0.4)$ \\
\hline Potentially Mineralizable Nitrogen (PMN) $\left(\mathrm{mg} \mathrm{kg}^{-1}\right)$ & $1.53(0.29)$ \\
\hline Dissolved Organic Carbon (DOC) $\left(\mathrm{mg} \mathrm{kg}^{-1}\right)$ & $282(12)$ \\
\hline Dissolved Organic Nitrogen (DON) $\left(\mathrm{mg} \mathrm{kg}^{-1}\right)$ & $2.09(0.55)$ \\
\hline Available Phosphorus (AP) $\left(\mathrm{mg} \mathrm{kg}^{-1}\right)$ & $0.27(0.01)$ \\
\hline Total $\mathrm{Pb}\left(\mathrm{mg} \mathrm{kg}^{-1}\right)$ & $733(29)$ \\
\hline Available $\mathrm{Pb}\left(\mathrm{mg} \mathrm{kg}^{-1}\right)$ & $111(8)$ \\
\hline Total Fe $\left(\mathrm{mg} \mathrm{kg}^{-1}\right)$ & $20,703(386)$ \\
\hline Available Fe $\left(\mathrm{mg} \mathrm{kg}^{-1}\right)$ & $8.87(0.48)$ \\
\hline
\end{tabular}

\subsection{Soil Pre-Incubation}

Collected soil was sieved to $<2 \mathrm{~mm}$ particle size and thoroughly homogenized by hand. Biochar, air-dried composted manure, and an inorganic fertilizer were applied to the soil as one-time applications at the beginning of a pre-incubation period, resulting in three "soil + amendment" treatments (BIOC, COMP, and INF, respectively), plus an unamended control soil (UNAM). Table 2 summarizes the chemical properties of the amendments. The biochar was obtained from High Plains Biochar in Laramie, WY, produced via pyrolysis of urban tree waste, primarily Populus deltoides L. (Plains Cottonwood), at $760-815^{\circ} \mathrm{C}$ for 10-15 min. The biochar was further treated with an EM- $1^{\circledR}$ microbial inoculant produced by Teraganix, along with worm casting tea and humic acid. The compost consisted of cow and horse manure mixed during stockpiling and aged outdoors for at least one year. It was sourced from the Livestock Unit of the University of Wyoming Laramie Research and Education Center. The inorganic fertilizer applied was commercially available watersoluble Miracle-Gro All Purpose Plant Food ${ }^{\mathrm{TM}}$.

Biochar and compost were both added at a rate equivalent to $7.5 \%$ of the total weight of the soil + amendment mixture (925 g soil: $75 \mathrm{~g}$ amendment). The treatments were thoroughly mixed by hand and, together with the unamended control, tap water was added to increase the moisture content to about $23 \%$ total moisture by weight, with native soil averaging about $4 \%$ moisture $(w / w)$ prior to amendment. Inorganic fertilizer was applied at a rate of $0.0075 \%$ crystals to soil $(w / w)$, or $0.75 \mathrm{~g}$ crystals: $10,000 \mathrm{~g}$ soil. A level tablespoon of crystals was weighed six times, establishing an average weight of $12.40 \mathrm{~g}$ of crystals per tablespoon. The crystals were dissolved in tap water at the manufacturer's recommended rate of one tablespoon per gallon for outdoor plants, or $12.40 \mathrm{~g}$ per $3785.41 \mathrm{~mL}$, then incorporated into soil to achieve $23 \%$ total moisture by weight.

The treatments were stored in plastic trays loosely covered with plastic wrap to reduce evaporation and kept in a dark room at $21^{\circ} \mathrm{C}$ for a pre-incubation period of 22 weeks. Soil moisture was monitored twice a week and additional tap water was added as needed to bring the moisture to about $23 \%$. No drainage was allowed in order to avoid leaching of nutrients or metals during pre-incubation. 
Table 2. Chemical properties of amendments prior to addition of native soil and water. The mineral composition of the inorganic fertilizer was sourced from the product label. Results for biochar and composted manure were obtained through laboratory testing. Use of " $\mathrm{n} / \mathrm{a}$ " in the table indicates that a specific element was not provided with the laboratory report or product label but does not necessarily suggest that the element is entirely absent.

\begin{tabular}{cccc}
\hline Chemical Composition & Biochar & Compost & Inorganic Fertilizer \\
\hline Carbon and Nitrogen: & & $-\%-$ & $\mathrm{n} / \mathrm{a}$ \\
Total Nitrogen & 0.42 & 1.24 & $\mathrm{n} / \mathrm{a}$ \\
Total Carbon & 65.10 & 8.57 & $\mathrm{n} / \mathrm{a}$ \\
C-to-N ratio & 154 & $7 \%-$ & $\mathrm{n} / \mathrm{a}$ \\
Macronutrients: & $\mathrm{n} / \mathrm{a}$ & 1.15 & 3.500 \\
Organic N & $\mathrm{n} / \mathrm{a}$ & 0.004 & 20.50 \\
Ammonium & $\mathrm{n} / \mathrm{a}$ & 0.086 & 8.00 \\
Nitrate & 0.11 & 0.85 & 16.00 \\
Available Phosphorus & $\mathrm{n} / \mathrm{a}$ & 2.13 & $\mathrm{n} / \mathrm{a}$ \\
Potassium & 3.21 & 3.93 & $\mathrm{n} / \mathrm{a}$ \\
Calcium & 0.39 & 0.68 & $\mathrm{n} / \mathrm{a}$ \\
Magnesium & 0.06 & 0.41 & 0.02 \\
Sulfur & & & 0.07 \\
Micronutrients: & 29.2 & 28.4 & 0.15 \\
Boron & $\mathrm{n} / \mathrm{a}$ & 23.3 & 0.05 \\
Copper & 181 & 8933 & 0.0005 \\
Iron & 51 & 241.6 & 0.06 \\
Manganese & 0.07 & $\mathrm{n} / \mathrm{a}$ & $\mathrm{n} / \mathrm{a}$ \\
Molybdenum & 53 & 95.7 & $-\%$ \\
Zinc & & 0.33 & \\
Trace Elements: & $\mathrm{n} / \mathrm{a}$ & & \\
Sodium & & & \\
\hline
\end{tabular}

\subsection{Lab Incubation and Greenhouse Experiment}

After pre-incubation, the amended soils were transported to the University of Wyoming College of Agriculture and Natural Resources Research and Extension Center Greenhouse Complex in Laramie, Wyoming. The temperature in the greenhouse was set to $21.1^{\circ} \mathrm{C}$ and $18.3^{\circ} \mathrm{C}$ during the day and night, respectively, with no supplemental lighting. Sixty-four plastic cone-tainers were filled with approximately 670 cubic centimeters of soil and planted with two varieties of vegetable seeds: a leafy green, Lactuca sativa L. (lettuce), and a root vegetable, Raphanus sativus L. (radish). The lettuce ("Emerald Jewel" cultivar) was obtained from Burpee in Warminster, Pennsylvania, and the radish (Rover F1 cultivar) was obtained from Johnny's Selected Seeds in Winslow, Maine. Both were kindly provided by Dr. Urszula Norton (University of Wyoming, Laramie, Wyoming).

The plants were chosen due to their commonality among local home gardeners and as representative species for above and belowground biomass, respectively. The conetainers had limited perforation at the bottom, allowing for leaching of the soil solution with minimal loss of treated soil. To increase the likelihood of germination for each replicate, cone-tainers planted with lettuce were seeded with four seeds and those with radish with two seeds. All cone-tainers were thinned to one plant per cone-tainer within a week of seedling emergence, except for those in which germination did not occur. The cone-tainers were arranged in an 8 cone-tainer $\times 8$ cone-tainer square using a completely randomized design. One additional layer of cone-tainers planted with radish were also placed on the outside of the experiment perimeter to act as an edge row and help reduce potential moisture loss.

Soil moisture was monitored and adjusted every one-to-two days to reach $20-30 \%$ $(w / w)$. This was achieved by comparing the weight of a cone-tainer at the ideal moisture content ("par weight") for the treatment type against the average weight (g) of two reference cone-tainers for each treatment and plant species combination. The average reference weight was subtracted from the ideal par weight to estimate moisture loss, then an equivalent amount of tap water was added as needed to each cone-tainer to bring it back up to the par weight for its species and treatment type. The experiment was terminated, and plants were harvested after 12 weeks in the greenhouse. 
Concurrent to the greenhouse experiment, a portion of the treated soils ("Lab Inc") continued to be incubated in the lab. This was done to assess soil microbially-driven transformations without the presence of plants. That portion of the treated soil continued to be stored and water content was monitored and adjusted using the same method as for pre-incubation until the greenhouse experiment was terminated (Figure 1).

\section{TREATMENTS}

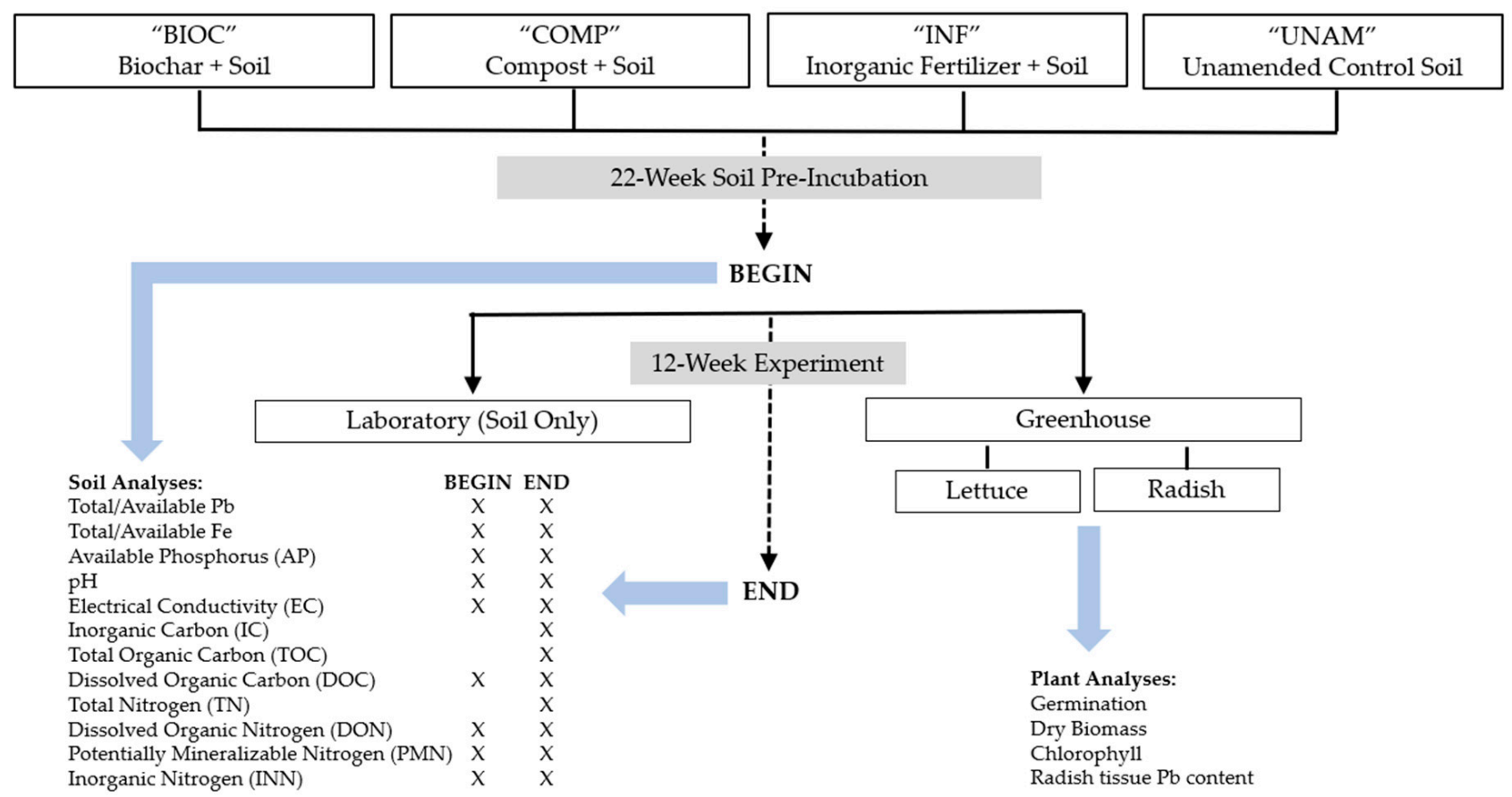

Figure 1. Graphical scheme of study design and analyses conducted.

\subsection{Soil Analyses}

Soil chemical analyses on both the native and treated included EC, $\mathrm{pH}, \mathrm{INN}$, potentially mineralizable nitrogen (PMN), dissolved organic carbon (DOC), dissolved organic nitrogen (DON), total inorganic carbon (TOC), total nitrogen (TN), inorganic C (IC), plantavailable phosphorus (AP), and total and available $\mathrm{Pb}$ and iron (Fe). Soil $\mathrm{pH}$ and EC were measured for greenhouse and lab-incubated soils at the beginning of the incubation, but only greenhouse soils at the end. Soil DOC and DON were tested at the beginning and end of the experiment. Inorganic $\mathrm{C}, \mathrm{TN}$, and TOC were only sampled once at the end of the experiment. Total and plant-available $\mathrm{Pb}$ and $\mathrm{Fe}$ concentrations were determined at the beginning of the incubation period, and available $\mathrm{Pb}$ and Fe were also measured at termination. All soil data were expressed on an oven-dried basis prior to statistical analysis.

Soil $\mathrm{pH}$ and EC were determined using a glass electrode and an Oakton 2700 series benchtop meter at a 1:2 soil-to-water ratio. Inorganic nitrogen content was calculated by combining soil ammonium $\left(\mathrm{NH}_{4}{ }^{+}\right)$and nitrate $\left(\mathrm{NO}_{3}{ }^{-}\right)$into one parameter. Ten grams of fresh soil were added to $25 \mathrm{~mL}$ of two molar potassium chloride $(2 \mathrm{M} \mathrm{KCl})$, placed on a shaker for $30 \mathrm{~min}$, and filtered through ash-free filter paper (Q5 Fischer Scientific, Waltham, MA, USA) [64]. The extract was then analyzed on a spectrophotometer microplate reader (UV-VIS Biotek Instruments, Highland Park, IL, USA) for $\mathrm{NH}_{4}{ }^{+}$using sodium salicylate (Reagent A) and two percent bleach mixed with $1.5 \mathrm{M}$ sodium hydroxide (Reagent B) [64]. Soil $\mathrm{NO}_{3}{ }^{-}$was also extracted using $2 \mathrm{M} \mathrm{KCl}$ and analyzed on the microplate reader following the vanadium chloride method [65]. Potentially mineralizable nitrogen (PMN) was assessed by incubating five grams of fresh soil in $12.5 \mathrm{~mL}$ of deionized water for 14 days at $25^{\circ} \mathrm{C}$ to create an anaerobic environment [66]. Oxygen present in the headspace of the centrifuge tube was flushed with dinitrogen $\left(\mathrm{N}_{2}\right)$ gas prior to sealing the tube. After two 
weeks, $12.5 \mathrm{~mL}$ of $0.5 \mathrm{M} \mathrm{K}_{2} \mathrm{SO}_{4}$ was added, the mixture was shaken for $30 \mathrm{~min}$, and filtered through ash-free filter paper (Q5 Fischer Scientific, Waltham, MA, USA). The resulting extract was then analyzed using a spectrophotometer microplate reader (UV-VIS Biotek Instruments, Highland Park, IL, USA), with PMN calculated as the difference between preand post-incubation $\mathrm{NH}_{4}{ }^{+}$concentrations.

A subsample of dried biomass was finely ground with a Willey Mill (Willey Laboratory Mill, Model 4, Arthur H. Thomas Co., Philadelphia, PA, USA) and passed through a $1 \mathrm{~mm}$ screen. Ground plant material was wrapped in tin capsules and analyzed for total carbon (TC) and total nitrogen (TN) by dry combustion using a Carlo Erba CN $2100 \mathrm{CN}$ analyzer (Carlo Erba Instruments, Milan, Italy). Soil TN comprised organic N, ammonia $\left(\mathrm{NH}_{3}{ }^{-}\right), \mathrm{NH}_{4}{ }^{+}, \mathrm{NO}_{3}{ }^{-}$, and nitrite $\left(\mathrm{NO}_{2}{ }^{-}\right)$. Dissolved organic carbon (DOC) and dissolved organic nitrogen (DON) concentrations were analyzed using the Newcomb-Carrillo method (2011) [67], with 1:2.5 soil:0.5 $\mathrm{M} \mathrm{K}_{2} \mathrm{SO}_{4}$ shaken for $30 \mathrm{~min}$, stored at $4{ }^{\circ} \mathrm{C}$ overnight, and filtered through ashless filter paper (Q5 Fisher Scientific, Waltham, MA, USA). Samples were analyzed on a total organic carbon (TOC) analyzer (Shimadzu TOC-VCPH with TNM1, Kyoto, Japan). Soil IC was determined via the pressure-calcimeter method outlined by Sherrod et al. (2002) [68]. Total organic carbon was calculated as the difference between total C and IC. Available P was estimated using the Olsen P method [69].

Available concentrations of $\mathrm{Pb}$ and Fe were quantified through DTPA extraction [70] and analyzed using inductively coupled plasma-optical emission spectrometry (ICP-OES). Total $\mathrm{Pb}$ and Fe contents were quantified using an Olympus Vanta ${ }^{\mathrm{TM}} \mathrm{X}$-ray fluorescence analyzer (XRF) after grinding 20-30 g of treated soil to a fine powder with a mortar and pestle.

\subsection{Plant Analyses}

Three chlorophyll measurements were taken and averaged on the first fully developed radish or lettuce leaf using a Konica Minolta SPAD 502 Plus meter. After measuring chlorophyll, the plants were gently removed from soil, rinsed with tap water to remove treatment residues, and separated by aboveground (stem and leaves) and belowground (root tissue) biomass by severing the plants at the base of the stem. For radish, root tissue refers to the tuberous portion. Samples were oven-dried at $65{ }^{\circ} \mathrm{C}$ for $24 \mathrm{~h}$ and the dry weights were recorded.

Lettuce did not produce enough biomass to conduct elemental analysis. Lead concentrations for above and below-ground tissue in radish were quantified using a dry ashing procedure [71]. Composite samples were used to produce as many unique root and shoot observations as possible for each treatment. One gram of dried, homogenized radish tissue was placed in a porcelain crucible soaked overnight in nitric acid $\left(\mathrm{HNO}_{3}\right)$. The tissue was then ashed at $500^{\circ} \mathrm{C}$ in a muffle furnace for four hours. Once cooled, ten drops of deionized (DI) water and $2 \mathrm{~mL}$ of $50 \%(v / v)$ nitric acid were added to each crucible and evaporated to dryness on a hot plate. The samples were ashed again for another $30 \mathrm{~min}$ at $450{ }^{\circ} \mathrm{C}$, with the remaining ash dissolved in $2 \mathrm{~mL}$ of $20 \%(v / v) \mathrm{HNO}_{3}$ on a hot plate heated to about $100{ }^{\circ} \mathrm{C}$. The solution was filtered through Whatman No. 42 filter paper, with the first two $\mathrm{mL}$ of filtrate discarded. Extracts were analyzed using ICP-OES.

\subsection{Plant Lead Uptake Indicators}

As a proxy for the amount of the $\mathrm{Pb}$ taken up by an individual radish plant within a treatment, a tissue "mass load" was calculated as follows (Equation (1)):

$$
\text { Mass load }\left(\frac{\mu \mathrm{g}}{\text { plant }}\right)=\text { Average Tissue Pb }\left(\frac{\mathrm{mg}}{\mathrm{kg}}\right) \times \text { Plant Biomass }(\mathrm{kg}) \times 10^{9}
$$


A bioconcentration factor (BCF), or measure of a plant's uptake relative to its level of soil exposure, was calculated for each treatment using a modified version of the approach described by Antonangeli and Zhang (2020) [72] and Ahmad et al. (2018) [73] (Equation (2)):

$$
\mathrm{BCF}=\frac{\text { Root Pb Concentration }+ \text { Average Shoot Pb Concentration }}{\text { Average Total Soil Pb Concentration }}
$$

To calculate $\mathrm{BCF}$, we added the average composite radish shoot concentration $\left(\mathrm{mg} \mathrm{kg}^{-1}\right)$ for the treatment to each composite radish root sample obtained to approximate total $\mathrm{Pb}$ concentration. An average shoot concentration was used because there were limited representative samples ( $n=3$ per treatment) for radish shoot tissue. The total concentration was then divided by the total amount of $\mathrm{Pb}$ present in the soil at that beginning of the experiment. We also calculated a translocation factor (TF) for each treatment, which characterizes a plant's ability to translocate $\mathrm{Pb}$ from roots to shoots. We adapted the equation from Ahmad, et al. (2018) [73] by substituting plant mass load for tissue concentration (Equation (3)):

$$
\mathrm{TF}=\frac{\text { Shoot } \mathrm{Pb} \text { Mass Load }}{\text { Root Pb Mass Load }}
$$

\subsection{Statistical Analyses}

The experimental design included eight replicates of the four treatments for both radish and lettuce, along with lab incubated soil. All analyses were performed in $\mathrm{R}$ version 3.6.2 (The R Foundation for Statistical Computing). The effects of amendment and plant species/Lab-Inc on available $\mathrm{Pb}$, key soil, and plant parameters, and changes in available $\mathrm{Pb}$ over time, were assessed using a two-way Analysis of Variance (ANOVA). Data were tested for normality using the Shapiro-Wilk test. Transformations were used to achieve normality for data that were not normally distributed. Tukey HSD was used to determine treatment significance at $p \leq 0.05$. If data were unable to normalize, a Kruskal-Wallis rank sum test was performed using a Dunn's test to determine means separation for statistically significant results. Pearson's correlation test was used to measure the strength of associations between soil available $\mathrm{Pb}, \mathrm{BCF}$, and mass load against the soil and plant parameters described above. Observations were considered significant at $p \leq 0.05$. All data presented in this chapter are untransformed. Correlations were analyzed three ways: using the dataset as a whole, inclusive of all data points from radish, lettuce, and lab-incubated samples, and with no separation by treatment; by treatment, using all data points from radish, lettuce, and lab-incubated samples available for that treatment; and by treatment with data points from radish or lettuce only.

\section{Results}

\subsection{Beginning of the Experiment}

Soil pH was greatest in BIOC (8.4) as compared to other treatments (Table 3). Remaining treatments were comparable to each other (7.8). Soil EC was the greatest in COMP $\left(1209 \mu \mathrm{S} \mathrm{cm}^{-1}\right)$ and twice as great as EC in UNAM $\left(537 \mu \mathrm{S} \mathrm{cm}^{-1}\right)$.

Soil INN in soil amended with BIOC was the lowest $\left(15.2 \mathrm{mg} \mathrm{kg}^{-1}\right)$ compared to other treatments (183.4 $\mathrm{mg} \mathrm{kg}^{-1}$ ) (Table 4) and soil PMN was very low to negligible. The BIOC treatment also had the least DON (12.5 $\left.\mathrm{mg} \mathrm{kg}^{-1}\right)$ while DON in INF was the greatest $\left(101.5 \mathrm{mg} \mathrm{kg}^{-1}\right)$. Soil DOC demonstrated an opposite pattern with the greatest concentrations observed in BIOC (398.9 $\left.\mathrm{mg} \mathrm{kg}^{-1}\right)$ and least in INF $\left(163.0 \mathrm{mg} \mathrm{kg}^{-1}\right)$.

The COMP treatment had the greatest AP $\left(0.6 \mathrm{mg} \mathrm{kg}^{-1}\right)$ compared to UNAM $\left(0.3 \mathrm{mg} \mathrm{kg}^{-1}\right)$ while AP concentrations in the other treatments fell in between. Soil available and total Fe concentrations averaged $8.6 \mathrm{mg} \mathrm{kg}^{-1}$ and 21,177 $\mathrm{mg} \mathrm{kg}^{-1}$, respectively, across all treatments. Available and total $\mathrm{Pb}$ concentrations averaged $104.5 \mathrm{mg} \mathrm{kg}^{-1}$ and $772 \mathrm{mg} \mathrm{kg}^{-1}$, respectively. 
Table 3. Soil physicochemical properties: $\mathrm{pH}$, electrical conductivity (EC), inorganic carbon (IC), total organic $\mathrm{C}$ (TOC), total nitrogen $(\mathrm{TN})$, and $\mathrm{C}$ to $\mathrm{N}$ ratio $(\mathrm{C}: \mathrm{N})$ in soils amended with biochar (BIOC), compost (COMP), inorganic fertilizer (INF), and from unamended control (UNAM). Values represent mean averages with standard errors in parentheses. Measurements at the beginning of the experiment before plant seeding are denoted as "Begin." Measurements at the end of the experiment are marked "End." The data are provided for individual plant species (End Radish and End Lettuce) and lab incubated soil (End Lab Inc.) if statistical differences existed among these groups for each soil treatment or, alternately, presented across all samples if there were no differences between groups ("All"). Lowercase letters indicate statistically significant differences by treatment. If there were no differences between treatments, "ns" is indicated. Statistical tests were performed using a two-way Analysis of Variance (ANOVA) or Kruskal-Wallis if data could not be normalized. Tukey HSD or Dunn's test were used to determine treatment significance of $p \leq 0.05$ at minimum.

\begin{tabular}{|c|c|c|c|c|c|c|}
\hline Soil Physicochemical Properties & BIOC & COMP & INF & UNAM & F-Stat & $p$-Value \\
\hline \multicolumn{7}{|l|}{ pH (1:2 soil: water) } \\
\hline Begin & $8.4(0.10) \mathrm{a}$ & $7.8(0.00) \mathrm{b}$ & $7.7(0.10) b$ & $7.9(0.00) b$ & 26.38 & $\leq 0.001$ \\
\hline \multirow{2}{*}{\multicolumn{7}{|c|}{$\mathrm{EC}\left(\mu \mathrm{S} \mathrm{cm}{ }^{-1}\right)$}} \\
\hline & & & & & & \\
\hline Begin & $689(23) b c$ & $1209(84) \mathrm{a}$ & $956(49) a b$ & $537(20) c$ & 22.67 & $\leq 0.001$ \\
\hline End Radish & $464(14) \mathrm{b}$ & $615(32) a$ & $434(12) \mathrm{b}$ & $472(27) \mathrm{b}$ & 8.86 & $\overline{\leq} 0.001$ \\
\hline \multirow{2}{*}{\multicolumn{7}{|c|}{ IC $\left(\mathrm{mg} \mathrm{kg}^{-1}\right)$}} \\
\hline & & & & & & \\
\hline End (All) & $17,457(714)$ & $15,971(701)$ & $16,774(813)$ & $17,007(559)$ & 0.79 & ns \\
\hline TOC $\left(\mathrm{mg} \mathrm{kg}^{-1}\right)$ & & & & & & \\
\hline & $78,043(1778)$ a & $35,465(1422) b$ & $30,887(1252) b$ & $33,977(1247) b$ & 32.08 & $\leq 0.001$ \\
\hline \multicolumn{5}{|l|}{$\mathrm{TN}\left(\mathrm{mg} \mathrm{kg}^{-1}\right)$} & & \\
\hline End Radish & $2221(29) \mathrm{ab}$ & $2279(67) \mathrm{a}$ & $2064(37) \mathrm{b}$ & $2134(32) \mathrm{ab}$ & 4.12 & $\leq 0.05$ \\
\hline End Lettuce & $2220(35) b$ & $2528(53)$ a & $2130(64) \mathrm{b}$ & $2022(23) \mathrm{c}$ & 21.2 & $\overline{\leq} 0.001$ \\
\hline \multicolumn{7}{|l|}{ Soil C:N Ratio } \\
\hline End (All) & $42.30(0.79)$ a & $21.11(0.36) \mathrm{b}$ & $23.41(0.32) b$ & $25.04(0.31) b$ & 40.80 & $\leq 0.001$ \\
\hline
\end{tabular}

Table 4. Soil Labile carbon $(\mathrm{C})$ and $\mathrm{N}(\mathrm{N})$ concentrations: dissolved organic $\mathrm{C}(\mathrm{DOC})$, dissolved organic nitrogen $(\mathrm{N})$, potentially mineralizable $\mathrm{N}(\mathrm{PMN})$, and inorganic $\mathrm{N}$ (nitrate and ammonium; INN) in soils amended with biochar (BIOC), compost (COMP), inorganic fertilizer (INF), and from unamended control (UNAM). Values represent mean averages with standard errors in parentheses. Measurements at the beginning of the experiment before plant seeding are denoted as "Begin." Measurements at the end of the experiment are labeled as "End." The data are provided for individual plant species (End Radish, End Lettuce) or lab-incubated (End Lab-Inc) samples if statistical differences existed between the groups or, alternately, across all samples if there were no differences ("All"). Lowercase letters in a row indicate statistically significant differences by treatment within each group. No differences between treatments are marked as "ns." Asterisks indicate a significant difference between Begin and End concentrations over time. Concentrations below the instrument's detection limit are marked as "<d.l." Statistical tests were performed using a two-way Analysis of Variance (ANOVA) or Kruskal-Wallis if data could not be normalized. Tukey HSD or Dunn's test were used to determine treatment significance at $p \leq 0.05$ at minimum.

\begin{tabular}{|c|c|c|c|c|c|c|}
\hline $\begin{array}{l}\text { Soil Labile } \\
\text { C and N } \\
\text { Properties }\end{array}$ & BIOC & COMP & INF & UNAM & F-Stat & $p$-Value \\
\hline \multicolumn{7}{|l|}{$\mathrm{DOC}\left(\mathrm{mg} \mathrm{kg}^{-1}\right)$} \\
\hline Begin & 398.85 (58.12) a & 270.69 (14.38) ab & 163.03 (13.5) b & $212.50(11.91) b$ & 7.06 & $\leq 0.05$ \\
\hline End Lab Inc & $298.97(23.06) \mathrm{ab}$ & $389.10(17.38) a$ * & $243.16(30.09) b$ & $188.20(27.27) \mathrm{b}$ & 7.89 & $<0.01$ \\
\hline End Radish & $48.40(12.10) \mathrm{C}^{*}$ & $132.68(11.83) \mathrm{b}$ * & $198.24(16.28) \mathrm{a}$ & $112.20(9.62) b^{*}$ & 17.76 & $\leq 0.001$ \\
\hline End Lettuce & $126.05(13.99) b$ * & $213.44(18.12) \mathrm{a}$ & $111.81(6.02) b$ * & $147.80(14.43) \mathrm{ab}$ * & 6.86 & $\leq 0.01$ \\
\hline \multicolumn{7}{|l|}{ DON $\left(\mathrm{mg} \mathrm{kg}^{-1}\right)$} \\
\hline Begin & $12.45(0.25) \mathrm{c}$ & $75.48(10.88) \mathrm{ab}$ & 101.50 (15.57) a & $28.33(3.23) b c$ & 12.21 & $\leq 0.01$ \\
\hline End Lab Inc & $19.83(0.11) \mathrm{ab}$ * & $92.08(0.51) \mathrm{a}$ & $58.38(1.47) \mathrm{ab}$ & $11.80(0.35) b^{*}$ & 10.39 & $\leq 0.05$ \\
\hline End Radish & $3.41(0.17) b$ * & $9.13(1.36) a^{*}$ & $9.21(3.24) a^{*}$ & $8.70(2.31) a^{*}$ & 12.31 & $\overline{\leq} 0.001$ \\
\hline End Lettuce & $19.91(3.73) b$ & $42.06(6.78) a b$ * & $64.40(14.53) \mathrm{a}$ & $18.44(2.13) b$ & 4.65 & $\leq 0.05$ \\
\hline \multicolumn{7}{|l|}{ PMN (mg kg $\left.{ }^{-1}\right)$} \\
\hline Begin & $1.64(0.96)$ & $5.69(1.36)$ & $<$ d.l. & $4.23(0.61)$ & 5.52 & $\leq 0.05$ \\
\hline End Lab Inc & $0.36(0.08) \mathrm{b}$ & $3.45(0.36) \mathrm{a}$ & $1.45(0.41) \mathrm{ab}$ & $3.13(1.03) \mathrm{ab}$ & 4.54 & $\leq 0.05$ \\
\hline End Radish & $3.02(0.27) c$ & $10.63(1.55) \mathrm{a}$ & $8.64(1.55) \mathrm{ab}$ & $5.49(0.88) \mathrm{b}$ & 7.03 & $\leq 0.01$ \\
\hline End Lettuce & $<$ d.1. & $6.89(0.83) \mathrm{a}$ & $2.74(0.45) b$ & $1.18(0.20) b^{*}$ & 61.10 & $\overline{\leq} 0.01$ \\
\hline \multicolumn{7}{|l|}{ INN (mg kg$\left.{ }^{-1}\right)$} \\
\hline Begin & $15.2(1.22) b$ & $195.16(17.54) \mathrm{a}$ & $217.12(25.10) \mathrm{a}$ & $137.76(21.14) \mathrm{a}$ & 15.75 & $\leq 0.01$ \\
\hline End Lab Inc & $65.73(5.36) c^{*}$ & $207.11(9.01) \mathrm{a}$ & $150.51(3.13) \mathrm{b}$ & $22.07(0.59) \mathrm{d}$ * & 153.70 & $\leq 0.001$ \\
\hline End Radish & $1.77(0.18)$ * & $6.68(1.70)$ * & $6.20(1.71) *$ & $6.79(1.62) *$ & 1.91 & ns \\
\hline End Lettuce & $16.70(2.48)$ & $16.04(1.25)$ * & $14.33(0.66)$ * & $14.28(2.06)$ * & 0.30 & ns \\
\hline
\end{tabular}




\subsection{Experiment Termination}

\subsubsection{Soil Physicochemical Properties}

Soil $\mathrm{pH}$ and EC remained unchanged over time. Soil inorganic $\mathrm{C}$ (measured only at the end of the experiment) averaged $16,802 \mathrm{mg} \mathrm{kg}^{-1}$ across all treatments. Total organic $\mathrm{C}$, also only measured at the end of the experiment, was significantly greater in BIOC $\left(78,043 \mathrm{mg} \mathrm{kg}^{-1}\right)$ than the other treatments, which averaged 33,443 $\mathrm{mg} \mathrm{kg}^{-1}$. The C:N ratio was the greatest in BIOC (42:1), and nearly twice as much as in the other treatments (23:1).

In lab-incubated soil, TN differed between treatments and followed the order of: $\operatorname{COMP}\left(2820 \mathrm{mg} \mathrm{kg}^{-1}\right) \geq$ BIOC $\left(2330 \mathrm{mg} \mathrm{kg}^{-1}\right) \geq \mathrm{INF}=$ UNAM (averaged $1937 \mathrm{mg} \mathrm{kg}^{-1}$ ). Among greenhouse samples, soil TN differed between treatments planted to radish and followed the order of: COMP $\left(2279 \mathrm{mg} \mathrm{kg}^{-1}\right) \geq$ BIOC $=$ UNAM (averaged $2178 \mathrm{mg} \mathrm{kg}^{-1}$ ) $\geq \operatorname{INF}\left(2064 \mathrm{mg} \mathrm{kg}^{-1}\right)$ and in treatments planted to lettuce: COMP $\left(2528 \mathrm{mg} \mathrm{kg}^{-1}\right)>$ BIOC $=$ INF (averaged $\left.2175 \mathrm{mg} \mathrm{kg}^{-1}\right) \geq$ UNAM $\left(2022 \mathrm{mg} \mathrm{kg}^{-1}\right.$ ).

\subsubsection{Soil Labile Nitrogen and Carbon}

Among lab-incubated samples, INN concentrations quadrupled in BIOC, declined by fivefold in UNAM, and no significant changes were observed in COMP and INF. Soil PMN decreased, regardless of treatment, with the greatest concentrations in COMP $\left(3.45 \mathrm{mg} \mathrm{kg}^{-1}\right)$ and the least in BIOC $\left(0.36 \mathrm{mg} \mathrm{kg}^{-1}\right)$. Soil DON increased in COMP only and resulted in the greatest concentration of all treatments $\left(92.08 \mathrm{mg} \mathrm{kg}^{-1}\right)$, unlike DON concentrations in UNAM, which decreased to $11.8 \mathrm{mg} \mathrm{kg}^{-1}$ and became the lowest. Significant reductions occurred in all treatments except for COMP.

Among greenhouse samples, INN declined in all treatments except for BIOC planted to lettuce. Soil PMN demonstrated no change except for a decline in UNAM also planted to lettuce. At the end of the experiment, the greatest PMN concentrations were observed in COMP and was the least in BIOC. Soil DON declined in all treatments planted to radish (between 91\% in INF and 69\% in UNAM) and in COMP planted to lettuce only (44.2\%). Soil DON concentrations were consistently greater in treatments planted to lettuce than radish. Soil DOC declined in all treatments except in INF and COMP, both planted to radish. The greatest reductions in DOC were observed in BIOC planted to radish $(88 \%)$ and lettuce $(68 \%)$. The smallest change in DOC was observed in UNAM. At the end of the experiment, INF planted to radish and COMP planted to lettuce had the greatest DOC concentrations.

\subsubsection{Soil Iron and Phosphorus}

Available P in lab-incubated soil increased significantly over time among all treatments except for COMP, but no statistical differences among treatments were observed at the end (Figure 2a). A significant reduction in available Fe from $8.5 \mathrm{mg} \mathrm{kg}^{-1}$ to $7.8 \mathrm{mg} \mathrm{kg}^{-1}$ was observed in COMP (Figure 2b). Available Fe was the greatest in UNAM and significantly greater than in COMP and INF.

Among greenhouse samples, soil AP significantly increased in all treatments. Specifically, COMP planted to radish had greatest soil AP $\left(2.1 \mathrm{mg} \mathrm{kg}^{-1}\right)$ followed by INF planted to radish $\left(1.6 \mathrm{mg} \mathrm{kg}^{-1}\right)$, with the least soil AP observed in BIOC $\left(0.9 \mathrm{mg} \mathrm{kg}^{-1}\right)$. Lettuce soil AP was the greatest in INF $\left(1.2 \mathrm{mg} \mathrm{kg}^{-1}\right)$ and the least in UNAM $\left(0.50 \mathrm{mg} \mathrm{kg}^{-1}\right)$. In contrast, significant reductions in soil Fe occurred in all treatments except for INF, with no statistical differences among treatments observed at the end.

\subsubsection{Soil Lead}

Available $\mathrm{Pb}$ concentrations were similar between the treatments at the beginning of the experiment and ranged from $83.5 \mathrm{mg} \mathrm{kg}^{-1}$ in COMP to $88.5 \mathrm{mg} \mathrm{kg}^{-1}$ in BIOC (Figure 3). Available $\mathrm{Pb}$ concentrations at the end however, differed depending on treatment. The greatest available $\mathrm{Pb}$ concentrations were in INF planted to radish and lettuce (100.9 $\mathrm{mg} \mathrm{kg}^{-1}$ and $96.3 \mathrm{mg} \mathrm{kg}^{-1}$, respectively) and the lowest available $\mathrm{Pb}$ concentrations were observed in BIOC planted to radish $\left(76.9 \mathrm{mg} \mathrm{kg}^{-1}\right)$. 


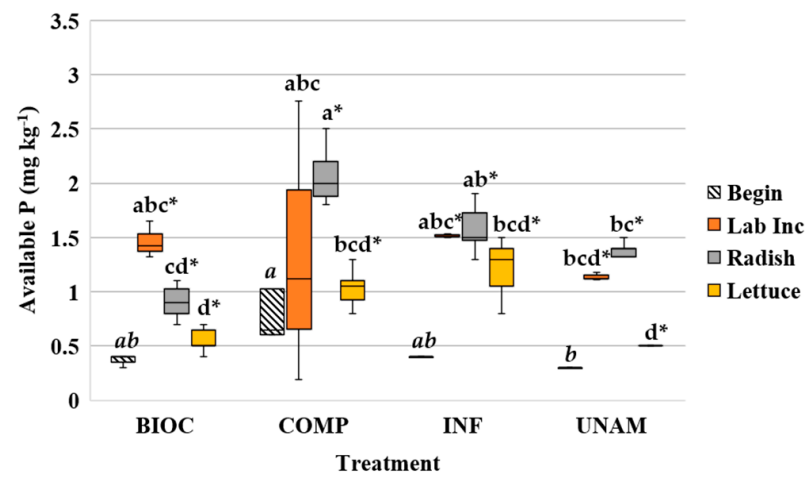

(a)

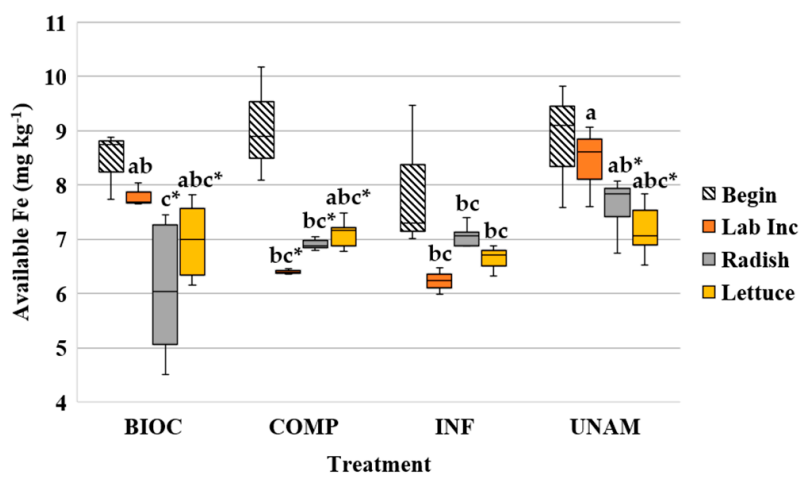

(b)

Figure 2. Soil available nutrient concentrations: (a) available phosphorus $(\mathrm{P})$ and $(\mathbf{b})$ iron $(\mathrm{Fe})$ in soils amended with biochar (BIOC), compost (COMP), inorganic fertilizer (INF), and unamended control (UNAM) at the beginning of the experiment (Begin) presented next to a stepwise comparison of final concentrations for soils planted to radish, lettuce, and lab-incubated soil (Lab Inc). Lower case letters represent statistically significant differences across all treatments and groups. Asterisks indicate a significant difference within each treatment in concentrations between Begin and end (Lab Inc, Radish and Lettuce). Statistical tests were performed using a two-way Analysis of Variance (ANOVA) or Kruskal-Wallis if data could not be normalized. Tukey HSD and Dunn's test (non-normal data) were used to determine treatment significance at a $p \leq 0.05$.

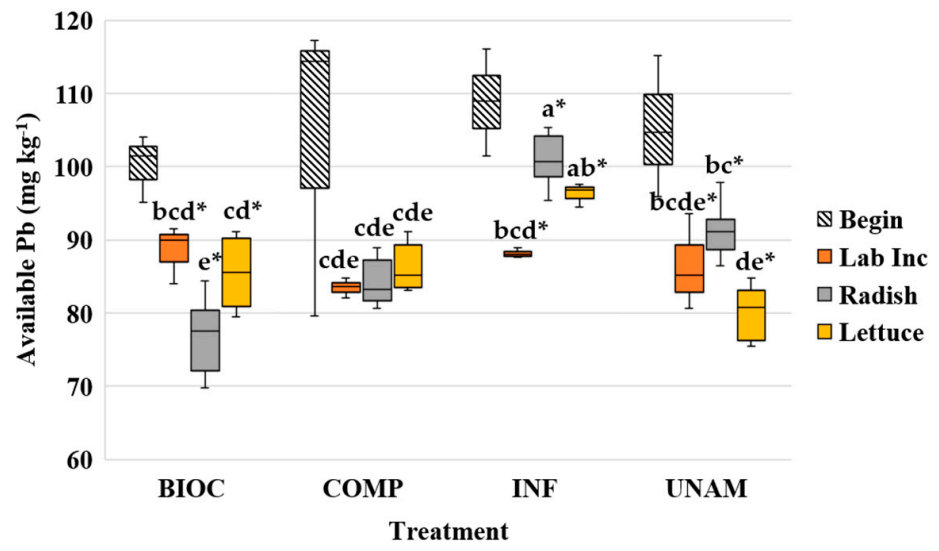

Figure 3. Available lead $(\mathrm{Pb})$ concentrations in soils amended with biochar (BIOC), compost (COMP), inorganic fertilizer (INF), and unamended control (UNAM) at the beginning of the experiment (Begin) presented next to a stepwise comparison of final concentrations for soils planted to radish, lettuce, and labincubated (Lab Inc). Lower case letters represent statistically significant differences across all treatments and life forms. Asterisks indicate a significant difference within each treatment in concentrations between Begin and end (Lab Inc, Radish, and Lettuce). Statistical tests were performed using a two-way Analysis of Variance (ANOVA) or Kruskal-Wallis if data could not be normalized. Tukey HSD and Dunn's test (non-normal data) were used to determine treatment significance at a $p \leq 0.05$.

Negative correlations between soil available $\mathrm{Pb}$ and soil $\mathrm{pH}, \mathrm{TOC}$, and $\mathrm{C}: \mathrm{N}$ ratio were observed using data from all groups (radish, lettuce, and Lab Inc) and treatments (Table 5). Soil pH measurement included radish and lettuce samples only (Figure 4). The observed relationship between $\mathrm{pH}$ and available $\mathrm{Pb}$ was driven by BIOC within the high range of $\mathrm{pH}$ values and by INF and COMP at the low end of $\mathrm{pH}$ values.

Comparing data by individual treatment (Table 6), available $\mathrm{Pb}$ was positively correlated with available Fe in both BIOC and INF (Figure 5). Available Pb in BIOC was positively correlated with DON (Figure 6a), negatively correlated with PMN (Figure 6b), and positively correlated with INN (Figure 6c). In contrast, available Pb in INF showed negative correlations with DON and INN, but a positive correlation with PMN, just like $\mathrm{Pb}$ in UNAM. Considering radish only, available $\mathrm{Pb}$ was correlated with soil TOC (Figure 7a), yet negatively correlated with soil DOC in BIOC and COMP (Figure 7b). 
Table 5. $p$-Values and correlation coefficients for the relationship between soil available lead $(\mathrm{Pb})$ and $\mathrm{pH}$, total organic carbon (TOC), $\mathrm{C}$ to nitrogen $(\mathrm{N})$ ratio $(\mathrm{C}: \mathrm{N})$, and available iron (Fe) across all treatments and plant species + lab incubated soil. Statistical analysis was conducted using Pearson's correlation test and observations were considered significant at $p \leq 0.05$.

\begin{tabular}{ccc}
\hline \multirow{2}{*}{ Soil Parameter } & \multicolumn{2}{c}{ Soil Available Pb } \\
\cline { 2 - 3 } & $p$-Value & Corr Coeff \\
\hline $\mathrm{pH}\left(1: 2, \mathrm{soill}_{\mathrm{H}} \mathrm{H}\right)$ & $\leq 0.001$ & -0.45 \\
$\mathrm{TOC}\left(\mathrm{mg} \mathrm{kg}^{-1}\right)$ & $\leq 0.001$ & -0.46 \\
$\mathrm{C}: \mathrm{N} \mathrm{Ratio}$ & $\leq 0.01$ & -0.36 \\
Available Fe $\left(\mathrm{mg} \mathrm{kg}^{-1}\right)$ & $\leq 0.01$ & 0.36 \\
\hline
\end{tabular}

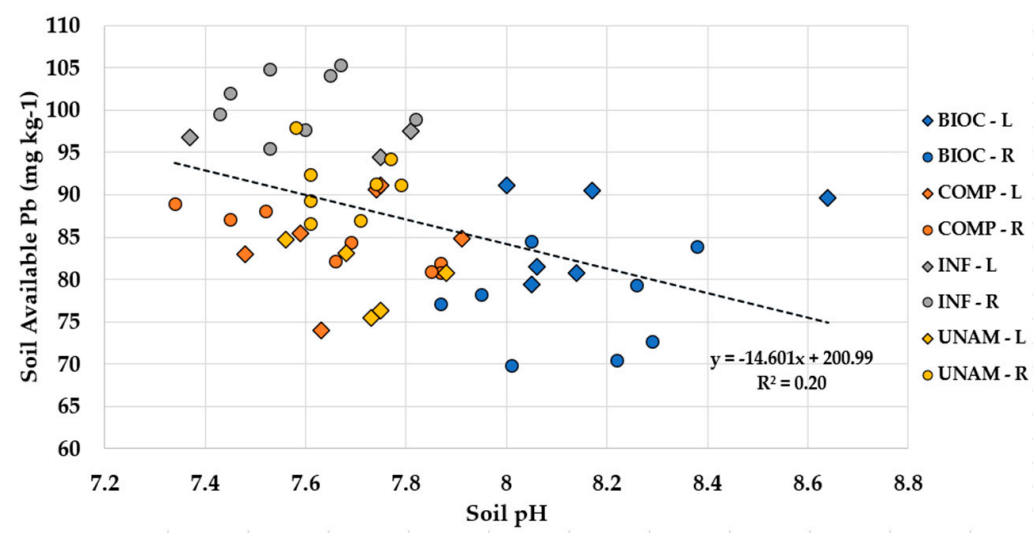

Figure 4. Correlation between soil $\mathrm{pH}$ and available soil lead $(\mathrm{Pb})$ among radish $(\mathrm{R})$ and lettuce $(\mathrm{L})$ samples. Colors represent different treatments (biochar, BIOC; compost, COMP, inorganic fertilizer, INF; and unamended control, UNAM) and shapes represent different life forms (diamond for lettuce and circle for radish). Statistical analysis was conducted using Pearson's correlation test and observations were considered significant at $p \leq 0.05$.

Table 6. $p$-Values and significant values of correlation coefficients representing relationships between soil available lead $(\mathrm{Pb})$ and $\mathrm{pH}$, electrical conductivity $(\mathrm{EC})$, potentially mineralizable $\mathrm{N}(\mathrm{PMN})$, inorganic $\mathrm{N}$ (ammonium and nitrate, INN), dissolved organic nitrogen (DON), dissolved organic carbon (DOC), available phosphorous (AP), C:N ratio, and available iron (Fe) for both plant species, plus lab incubated soil (All) or Radish and Lettuce separately in soils amended with biochar, BIOC; compost, COMP, inorganic fertilizer, INF, and unamended control, UNAM. Statistical analysis was conducted using Pearson's correlation test and observations were considered significant at $p \leq 0.05$ and analyses were performed on number of observations as indicated in brackets below the column headings.

\begin{tabular}{|c|c|c|c|c|c|c|c|c|}
\hline \multirow[t]{2}{*}{ Soil Parameter Correlate } & \multicolumn{2}{|c|}{ BIOC } & \multicolumn{2}{|c|}{ COMP } & \multicolumn{2}{|c|}{ INF } & \multicolumn{2}{|c|}{ UNAM } \\
\hline & $p$-Value & Corr Coeff & $p$-Value & Corr Coeff & $p$-Value & Corr Coeff & $p$-Value & Corr Coeff \\
\hline All & \multicolumn{2}{|c|}{$(n=17)$} & \multicolumn{2}{|c|}{$(n=17)$} & \multicolumn{2}{|c|}{$(n=14)$} & \multicolumn{2}{|c|}{$(n=16)$} \\
\hline $\mathrm{EC}\left(\mu \mathrm{sm}^{-1}\right)$ & $\leq 0.05$ & 0.57 & - & - & $\leq 0.05$ & -0.62 & - & - \\
\hline PMN (mg kg-1) & $\leq 0.01$ & -0.67 & - & - & $\leq 0.05$ & 0.61 & $\leq 0.10$ & 0.48 \\
\hline INN (mg kg-1) & $\leq 0.05$ & 0.52 & - & - & $\leq 0.001$ & -0.85 & - & - \\
\hline $\mathrm{DOC}\left(\mathrm{mg} \mathrm{kg}^{-1}\right)$ & $\leq 0.05$ & 0.51 & - & - & - & - & - & - \\
\hline $\mathrm{DON}\left(\mathrm{mg} \mathrm{kg}^{-1}\right)$ & $\overline{\leq} 0.01$ & 0.69 & - & - & $\leq 0.01$ & -0.68 & - & - \\
\hline $\mathrm{AP}\left(\mathrm{mg} \mathrm{kg}^{-1}\right)$ & - & & - & - & - & - & $\leq 0.001$ & 0.78 \\
\hline C:N Ratio & & 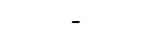 & - & - & - & - & $\leq 0.05$ & -0.52 \\
\hline $\begin{array}{c}\text { Available Fe }\left(\mathrm{mg} \mathrm{kg}^{-1}\right) \\
\text { Radish }\end{array}$ & \multicolumn{2}{|c|}{$(n=8)$} & \multicolumn{2}{|c|}{$(n=8)$} & \multicolumn{2}{|c|}{$(n=8)$} & \multicolumn{2}{|c|}{$(n=8)$} \\
\hline $\mathrm{DOC}\left(\mathrm{mg} \mathrm{kg}^{-1}\right)$ & $\leq 0.05$ & -0.77 & - & - & - & - & - & - \\
\hline TOC $\left(\mathrm{mg} \mathrm{kg}^{-1}\right)$ & $<0.01$ & 0.94 & $<0.01$ & 0.84 & _- & - & - & - \\
\hline C:N Ratio & $\leq 0.05$ & 0.83 & -0.01 & $\begin{array}{c}0.07 \\
-\end{array}$ & - & - & - & - \\
\hline $\mathrm{pH}\left(1: 2\right.$, soil: $\left.\mathrm{H}_{2} 0\right)$ & - & - & $\leq 0.001$ & -0.94 & - & - & - & - \\
\hline $\mathrm{DON}\left(\mathrm{mg} \mathrm{kg}^{-1}\right)$ & $\leq 0.05$ & -0.72 & - & - & - & - & - & - \\
\hline Available Fe $\left(\mathrm{mg} \mathrm{kg}^{-1}\right)$ & \multicolumn{2}{|c|}{$=0.01 \quad(n=6)^{0.00}$} & \multicolumn{2}{|c|}{$(n=6)$} & \multicolumn{2}{|c|}{$(n=3)$} & $(n=5)$ & - \\
\hline $\begin{array}{c}\text { Lettuce } \\
\text { Available Fe }\left(\mathrm{mg} \mathrm{kg}^{-1}\right)\end{array}$ & $\leq 0.01$ & b) 0.93 & - & - & - & - & - & - \\
\hline
\end{tabular}




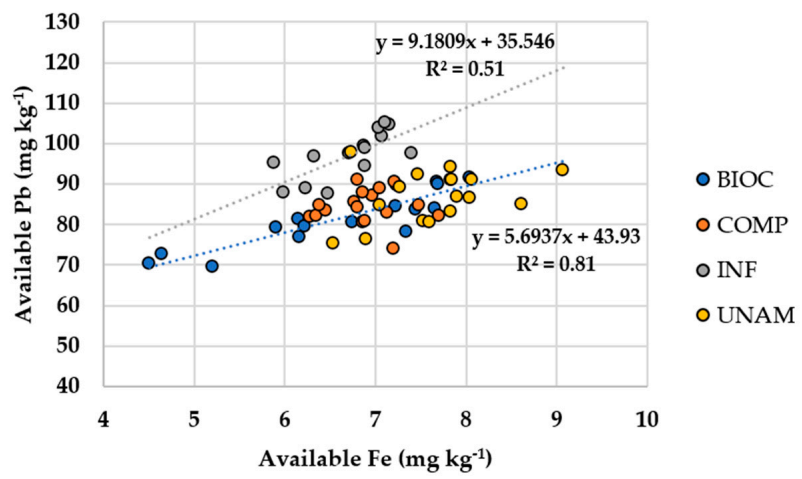

Figure 5. Relationship between soil available iron $(\mathrm{Fe})$ and available lead $(\mathrm{Pb})$ using data from both plant species and lab incubation at the end of the experiment. Colors represent different treatments (biochar, BIOC; compost, COMP, inorganic fertilizer, INF, and unamended control, UNAM). A regression line accompanied by the slope equation and an R-sq value is shown (INF and BIOC only) when significant.

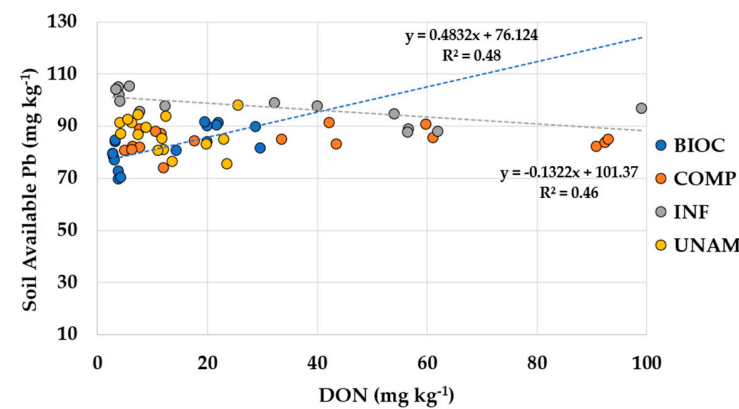

(a)

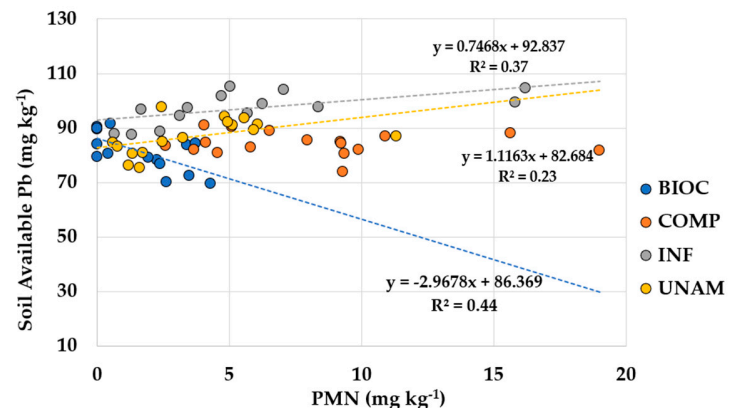

(b)

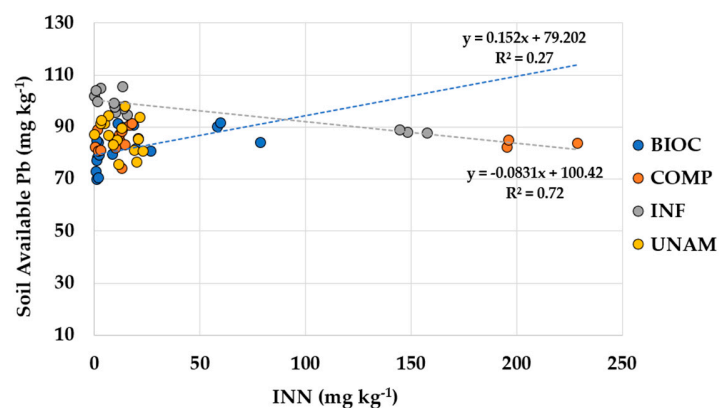

(c)

Figure 6. Relationship between soil available lead $(\mathrm{Pb})$ and soil nitrogen parameters: (a) dissolved organic nitrogen (DON); (b), potentially mineralizable $\mathrm{N}(\mathrm{PMN})$; and (c) and inorganic $\mathrm{N}$ (ammonium and nitrate). Colors represent different treatments (biochar, BIOC; compost, COMP, inorganic fertilizer, INF, and unamended control, UNAM) when a significant regression line accompanied by the slope equation and an R-sq value is shown for each individual amendment. 


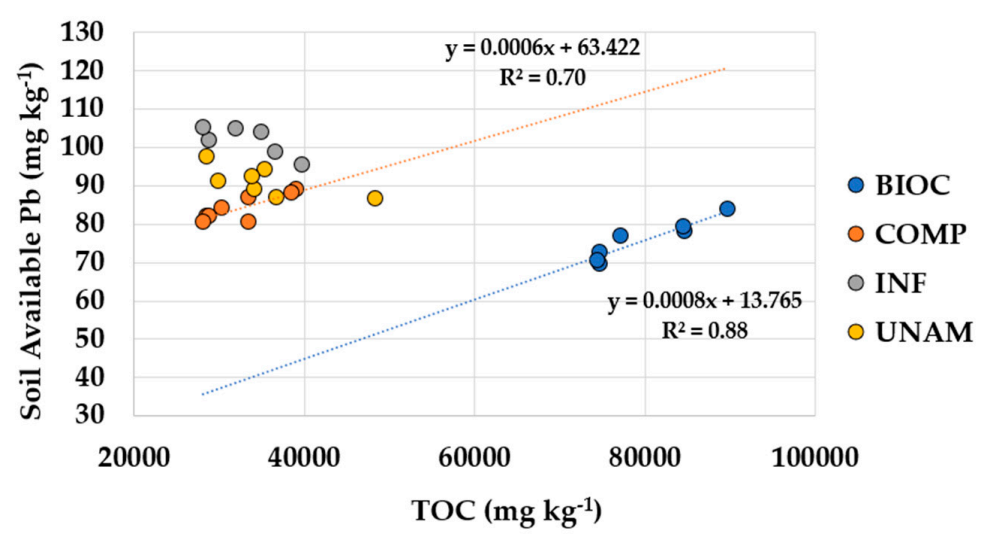

(a)

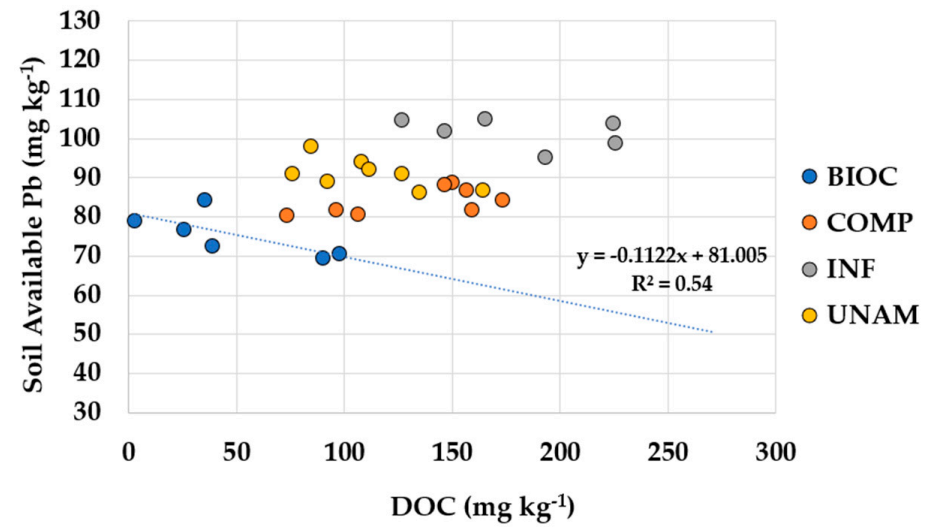

(b)

Figure 7. Relationship between soil available lead $(\mathrm{Pb})$ and soil carbon parameters: (a) total organic carbon (TOC); (b) and dissolved organic carbon (DOC). Colors represent different treatments (biochar, BIOC; compost, COMP, inorganic fertilizer, INF, and unamended control, UNAM). When significant, a regression line accompanied by the slope equation and an R-sq value is shown for each individual amendment.

\subsubsection{Plant Growth Parameters}

A 100\% germination rate occurred across all eight replicates among radish samples (Table 7). Root dry biomass in UNAM was the least $(1.01 \mathrm{~g})$, while the other treatments averaged $1.65 \mathrm{~g}$. No differences in shoot biomass were observed between all treatments. The resulting root-to-shoot ratio was least in UNAM. Leaf chlorophyll differed between treatments and followed the order of: UNAM $>$ COMP $=$ INF $>$ BIOC.

Among lettuce samples, germination was less successful, ranging between three (INF) and six seedlings (BIOC and COMP) out of eight cone-tainers seeded. Dry leaf biomass was not affected by treatment, but shoot-to-root ratio was the greatest in UNAM and the lowest in BIOC. Leaf chlorophyll followed the order of: UNAM $\geq$ COMP and INF $\geq$ BIOC.

\subsubsection{Lead Content and Uptake by Radish}

Shoot $\mathrm{Pb}$ content did not differ significantly among treatments and averaged $13.2 \mathrm{mg} \mathrm{kg}^{-1}$ (Figure 8a). There were also no significant differences in root $\mathrm{Pb}$ content among BIOC (29.4 $\mathrm{mg} \mathrm{kg}^{-1}$ ), COMP (40.8 $\mathrm{mg} \mathrm{kg}^{-1}$ ), and INF (56.8 $\mathrm{mg} \mathrm{kg}^{-1}$ ) relative to UNAM (42.7 $\mathrm{mg} \mathrm{kg}^{-1}$ ). However, root $\mathrm{Pb}$ content was significantly lower in BIOC than in INF. Plant Pb uptake, as measured by total mass load, was significantly greater in COMP $(87.5 \mu \mathrm{g})$ and INF $(89.1 \mu \mathrm{g})$ than in UNAM $(46.7 \mu \mathrm{g})$ and BIOC $(52.7 \mu \mathrm{g})$, which were statistically similar (Figure $8 \mathrm{~b}$ ). The BCF index showed that although none of the treatments were statistically different than UNAM (0.07), the BCF factors for COMP (0.08) and INF (0.09) were significantly greater than BIOC (0.05) (Figure 9a). The TF in COMP (0.14) was 
significantly greater than in UNAM (0.08) and INF (0.09), while BIOC (0.11) was similar to all treatments (Figure 9b).

Table 7. Plant growth parameters: number of plants germinated, dry root biomass, dry shoot biomass, leaf chlorophyll (SPAD), and root-to-shoot/shoot-to-root ratio (root:shoot/shoot:root) reported for radish and lettuce at the end of the experiment for soils amended with biochar (BIOC), compost (COMP), inorganic fertilizer (INF) and unamended control (UNAM). Lower case letters within each row represent statistical differences at a minimum of $p \leq 0.05$ or as indicated by F-stat and $p$-values in the last column. Statistical tests were performed using a two-way Analysis of Variance (ANOVA) or Kruskal-Wallis if data could not be normalized. Tukey HSD and Dunn's test (non-normal data).

\begin{tabular}{|c|c|c|c|c|c|c|}
\hline Plant Growth Parameters & BIOC & COMP & INF & UNAM & F-Stat & $p$-Value \\
\hline \multicolumn{7}{|l|}{ Radish } \\
\hline No. Germinated & 8 & 8 & 8 & 8 & & \\
\hline Dry Root Biomass (g) & $1.62(0.10) \mathrm{a}$ & $1.88(0.13)$ a & $1.46(0.14) \mathrm{ab}$ & $1.01(0.13) b$ & 7.41 & $<0.001$ \\
\hline Dry Shoot Biomass (g) & $0.49(0.04)$ & $0.55(0.05)$ & $0.44(0.08)$ & $0.45(0.04)$ & 0.77 & ns \\
\hline SPAD (SPAD units) & $29.38(0.87) \mathrm{c}$ & $32.88(0.39) \mathrm{b}$ & $33(0.84) b$ & 36.97 (1.07) a & 12.1 & $\leq 0.001$ \\
\hline Root:Shoot & $3.59(0.42) \mathrm{a}$ & $3.54(0.29) \mathrm{a}$ & $4.17(0.76) \mathrm{a}$ & $2.22(0.15) \mathrm{b}$ & 5.56 & $\leq 0.01$ \\
\hline $\begin{array}{c}\text { Lettuce } \\
\text { No. Germinated }\end{array}$ & & & & & & \\
\hline $\begin{array}{c}\text { No. Germinated } \\
\text { Dry Root Biomass }(g)\end{array}$ & $\begin{array}{c}6 \\
0.10(0.04)\end{array}$ & $\begin{array}{c}6 \\
0.19(0.06)\end{array}$ & 3 & $\begin{array}{c}5 \\
0.06(0.03)\end{array}$ & 323 & $\mathrm{~ns}$ \\
\hline Dry Shoot Biomass (g) & $\begin{array}{l}0.10(0.04) \\
0.09(0.03)\end{array}$ & $0.26(0.05)$ & $\begin{array}{l}0.17(0.03) \\
0.24(0.03)\end{array}$ & $0.18(0.10)$ & $\begin{array}{l}3.23 \\
2.77\end{array}$ & ns \\
\hline SPAD (SPAD units) & $19.70(3.49) \mathrm{b}$ & $30.83(2.36) \mathrm{ab}$ & $36.30(2.59) \mathrm{a}$ & $26.40(1.85) \mathrm{ab}$ & 4.38 & $\leq 0.05$ \\
\hline Shoot:Root & $1.23(0.15) \mathrm{b}$ & $1.37(0.90) \mathrm{ab}$ & $1.46(1.05) \mathrm{ab}$ & $3.17(3.04) \mathrm{a}$ & 4.25 & $\leq 0.05$ \\
\hline
\end{tabular}

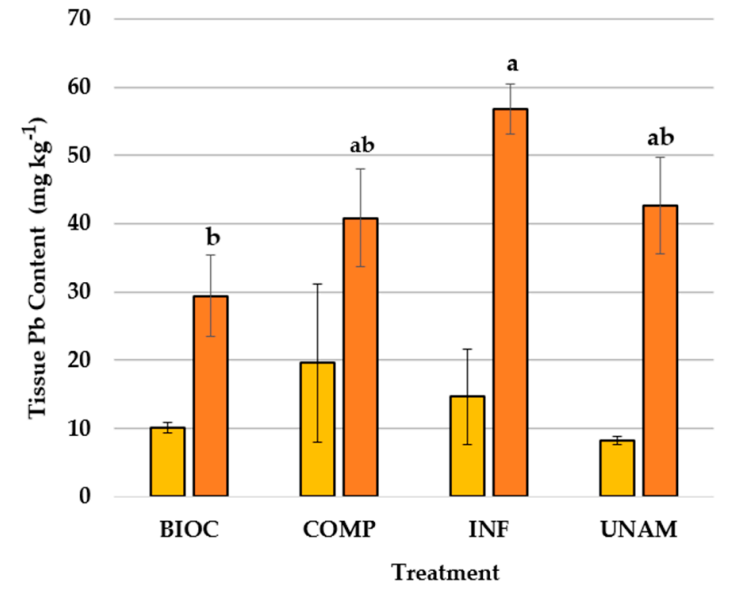

(a)

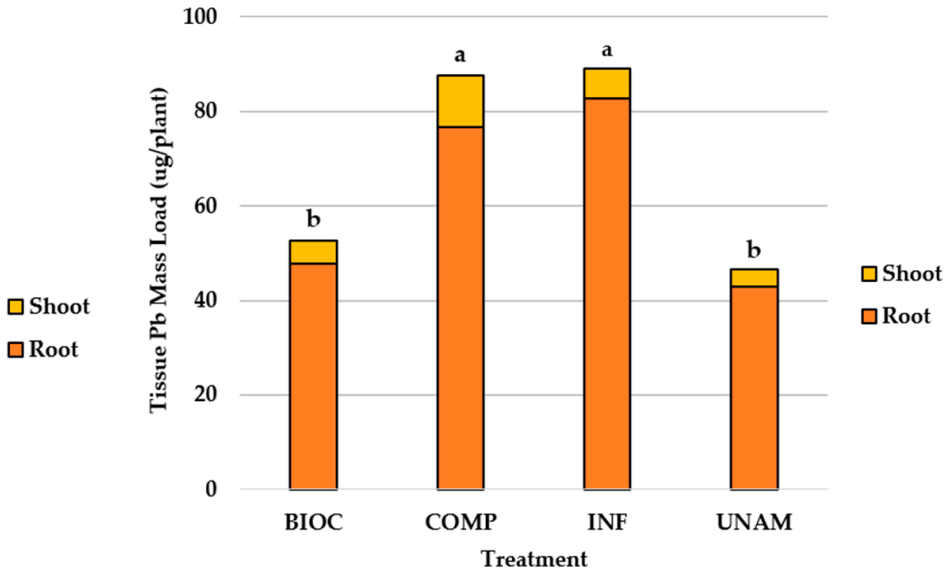

(b)

Figure 8. Radish $\mathrm{Pb}$ uptake measurements: (a) root and shoot tissue lead $(\mathrm{Pb})$ average concentrations accompanied by mean error bars; (b) average root and shoot mass loads for plants grown in soils amended with biochar (BIOC), compost (COMP), inorganic fertilizer (INF), and unamended control (UNAM). Lowercase letters on each figure indicate statistically significant differences between treatments. Statistical tests were performed using a two-way Analysis of Variance (ANOVA) or Kruskal-Wallis if data could not be normalized. Tukey HSD or Dunn's test (non-normal data) were used to determine treatment significance at a minimum of $p \leq 0.05$. 


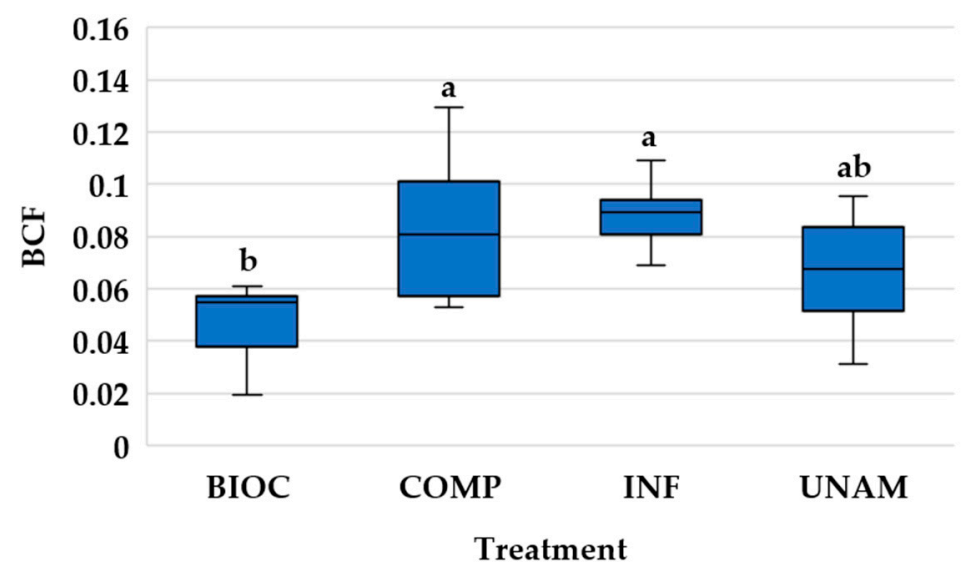

(a)

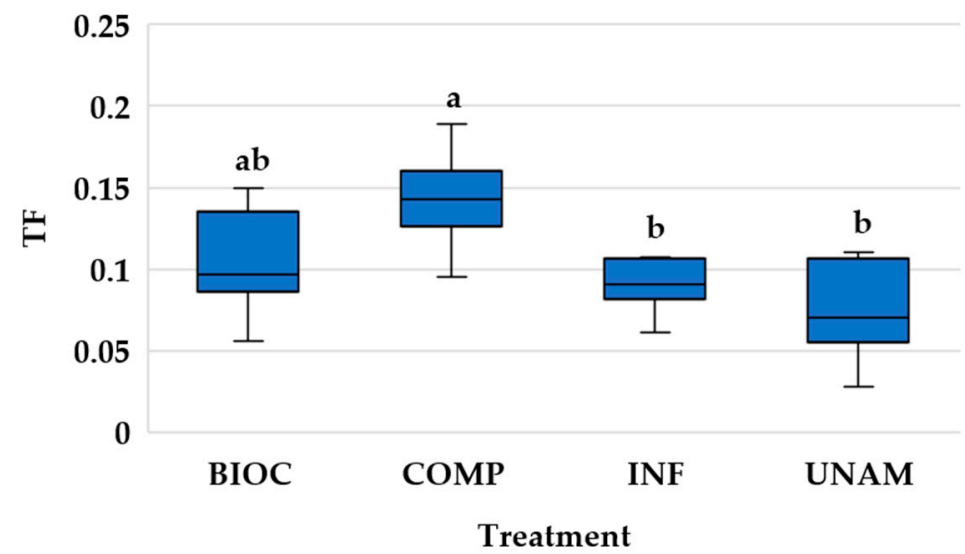

(b)

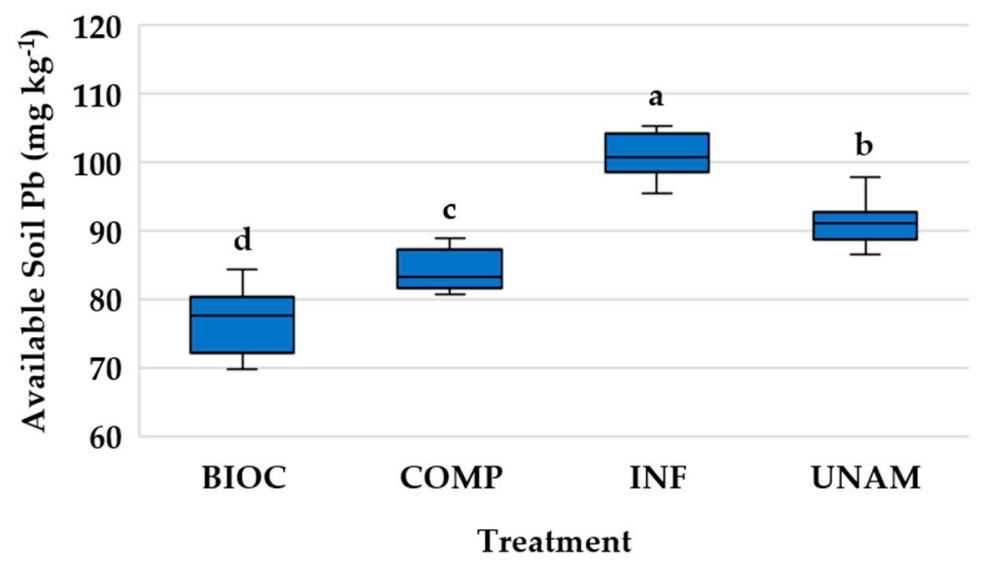

(c)

Figure 9. Lead uptake indicators and soil concentrations among radish samples: (a) bioconcentration factor (BCF); (b) translocation factor (TF); and (c) soil available lead (Pb) for radish grown in soils amended with biochar (BIOC), compost (COMP), inorganic fertilizer (INF) and unamended control (UNAM). Lowercase letters indicate statistically significant differences between treatments. Statistical tests were performed using a two-way Analysis of Variance (ANOVA) or Kruskal-Wallis if data could not be normalized. Tukey HSD and Dunn's test (non-normal data) were used to determine treatment significance at a minimum of $p \leq 0.05$. 


\section{Discussion}

\subsection{Amendments and Soil Properties}

In general, calcareous soils in arid climates have low OM and nutrient availability, especially available $\mathrm{P}$ and available Fe [51], making it difficult to successfully support crop growth without external inputs. Soil laboratory analyses suggest that the soil studied would benefit from the application of amendments rich in plant-available nutrients, particularly orthophosphates and INN, which both fell below optimal ranges for crop production $[74,75]$. Hence, the addition of amendments, such as locally produced biochar and composted manure, along with other additives like store-bought fertilizers, is a common step that many gardeners take to address these challenges.

\subsubsection{Soil Physicochemical Properties}

Amending soil did not affect IC concentrations. Amendments, however, affected soil $\mathrm{pH}$ and EC. It should be noted that changes to $\mathrm{EC}$ and $\mathrm{pH}$ occurred upon amendment application, with no significant changes to EC after the 22-week pre-incubation. Biochar was the only amendment that affected soil $\mathrm{pH}$ by making soil more alkaline. Greater biochar $\mathrm{pH}$ is generally correlated with greater ash content, which increases with increased pyrolysis temperatures [46]. Ippolito et al. (2020) suggest that the greater the pyrolysis temperature, the greater the loss of acidic functional groups, along with increased formation of $\mathrm{Ca}-, \mathrm{Mg}-, \mathrm{Na}$, and $\mathrm{K}$-bearing oxide, hydroxide, and carbonate mineral phases that can raise $\mathrm{pH}$ [46]. Because increased soil alkalinity can reduce the availability of certain nutrients (e.g., $\mathrm{Fe}$ ), the change in $\mathrm{pH}$ in BIOC underscores the importance of selecting a biochar made using an appropriate pyrolysis temperature and feedstock for the intended purpose and soil environment in which it will be used [46,47].

The addition of compost and inorganic fertilizer doubled the EC compared to UNAM and BIOC. Lack of EC response in BIOC may be due to the capacity of charcoal to sorb salts [76]. The increases observed in COMP and INF highlight the utility of amendments in increasing EC in low nutrient soils, where plant health and growth may be adversely impacted through nutrient deficiency. However, it also points to the potential for excessive EC levels through over-application of soil amendments. Excessive EC can prevent effective nutrient uptake by increasing the osmotic pressure of the nutrient solution and also promotes losses of nutrients through leaching [77].

\subsubsection{Biogeochemistry in the Absence of Plants}

Adding organic amendments modified soil TOC, TN, and the corresponding C:N ratio. Composition of these amendments depends on many factors. As noted above, biochar composition is heavily influenced by pyrolysis temperature and feedstock choice [46]. Our biochar originated from cottonwood chipped material and contained very high TOC (65.1\%) and very low TN (only $0.42 \%$ ). Consequently, BIOC had over double the soil TOC as UNAM. Knowing the chemical composition of biochar is therefore critical for making application recommendations. The high C:N ratio of the biochar used in this study (157) suggests that inherently low TN in native soil combined with low TN in biochar added will likely result in microbial $\mathrm{N}$ immobilization due to the initial stimulation of microbial growth that often accompanies the introduction of biochar-delivered DOC [45,52]. This scenario can induce plant $\mathrm{N}$ deficiencies. This was further supported by the fact that the application of biochar to native soil in this study $(7.5 \% w / w)$ resulted in a C:N ratio that was twice as high as the UNAM soils.

Compost TOC and TN contents depend on the length of time the compost ages and whether it originates from animal or plant organic materials [78]. In general, compost applications result in short-term increases in $\mathrm{TN}$, which depends on the frequency of application and the quantity applied $[79,80]$, along with the organic residue material from which it is derived [81]. The aged livestock manure used in this study contained three times as much TN and eight times less TOC than biochar. The compost addition therefore resulted in the greatest soil TN of all treatments, but similar TOC to INF and 
UNAM. High TN and low TOC in compost resulted in a very low C:N ratio (7) and hence stimulated rapid mineralization and formation of INN. However, by the end of the experiment, the C:N ratio of COMP was statistically similar to that of both UNAM and INF, suggesting that much of the readily decomposable content in COMP amendment had been mineralized. Alternatively, an application rate greater than $7.5 \%$ might have been required to substantively change the C:N ratio relative to UNAM.

Soil incubation in the absence of amendments or plants (UNAM Begin and UNAM End Lab Inc) resulted in significant declines to INN and DON over time. Local native soils are known to have high nitrification potential; hence the majority of INN represents soil nitrate (unpublished data). Inorganic $\mathrm{N}$ was comparable between COMP and INF, but it is unclear how the low soil $\mathrm{C}: \mathrm{N}$ ratio of the native soil predetermines soil $\mathrm{N}$ mineralization given UNAM had a similar C:N ratio to COMP and INF. Native soil enriched with organic amendments high in N (COMP and INF) had comparable INN and DON concentrations at the beginning of the experiment, however it was clear that COMP was more effective than INF in promoting soil labile $\mathrm{N}$ and $\mathrm{N}$ mineralization through decomposition (ca. 20-30\% annually), as demonstrated by the significantly greater concentrations of INN and DOC at the end of the experiment. In contrast, the trend observed in INF with respect to reductions in labile $\mathrm{N}$ over time, though not significant, point to the lack of a continual source of DON and INN without $\mathrm{OM}$ or an alternative slow-release $\mathrm{N}$ source.

The high soil C:N ratio in BIOC can partially explain the lowest INN and labile DON concentrations in the absence of plants at the beginning of the experiment. Biochar is also known to sequester labile forms of $\mathrm{N}$, particularly $\mathrm{NO}_{3}-\mathrm{N}$, primarily through sorption to base functional groups on the biochar surface [82,83] generated during pyrolysis. For this reason, we do not recommend that gardeners use most biochar as a primary $\mathrm{N}$ source. Instead, a supplemental source of $\mathrm{N}$ may be necessary to offset potential deficiency among crops. Nonetheless, significant increases in INN and DON suggests that, even though concentrations were the lowest of all treatments, biochar underwent decomposition and $\mathrm{N}$ mineralization. Variations among biochars can also affect the $\mathrm{N}$ mineralization-immobilization process differently [83]. For instance, manure biochar is more likely than plant-based biochar to stimulate $\mathrm{N}$ mineralization due to a lower C:N ratio [84]. Additionally, in a study of biochar made from four feedstocks (wood pellets, soft wood bark, switchgrass (Panicum virgatum L.) straw, and anaerobically digested fiber) and amended at three rates, Streubel et al. (2011) showed that soil type has a direct influence on $\mathrm{N}$ mineralization, in addition to application rate and feedstock [38].

As mentioned above, native soils appeared to have INN concentrations comparable to COMP and INF at the beginning of the experiment, following the 22-week pre-incubation. This points to the potential of native OM N priming in UNAM during pre-incubation. Nitrogen priming is a change in the soil mineralization process set off by a specific "trigger," like the addition of $\mathrm{N}$, mechanical disruption, or rhizodeposition, that increases or decreases microbial mineralization [85]. Thus, disruption of native soil and the addition of water that occurred during pre-incubation could have resulted in priming, followed by declines in INN and DON over time, as seen in UNAM.

\subsubsection{Soil Iron and Phosphorous in Absence of Plants}

Phosphorus and Fe are two important nutrients limiting plant growth in calcareous soils [86]. Although their soil total content may be high, both are largely unavailable to plants in this soil environment due to the poor solubility of cations at a high $\mathrm{pH}$. For every $\mathrm{pH}$ unit increase, for example, $\mathrm{Fe}^{3+}$ concentration decreases a thousand-fold [87]. Further, the high concentrations of Ca present readily precipitate with $\mathrm{P}$ as Ca-phosphate, which is released extremely slowly over time as the mineral weathers and dissolves, and also sorbs to Ca oxides in soil $[88,89]$. Observed increases in soil available P concentrations, which were similar among all treatments, were likely the result of increased microbial activity [51]. Similar available $\mathrm{P}$ increases have been described in other research documenting changes in soil properties through amendment with biochar and compost [51,90] However, using 
the Olsen P Method [69], an optimal range for available $\mathrm{P}$ in soil is $30-50 \mathrm{mg} \mathrm{kg}^{-1}$ [91], thus the increases observed were likely not sufficient to overcome symptoms of deficiency.

Our data suggests that none of the amendments were a significant source of Fe. Further, the availability of Fe was largely unaffected by the higher pH in BIOC, which was unexpected. Nonetheless, the difference in $\mathrm{pH}$ between BIOC and the other treatments did not appear to affect ecologically meaningful differences in terms of Fe availability. General decreases in available Fe observed across all treatments were also observed by Ippolito et al. (2014) [92]. Given the high concentrations of DOC and DON in COMP at the end of the experiment, the significant decrease in Fe in COMP and INF may be attributable to microbial immobilization and microbial biomass decomposition.

\subsubsection{Soil Biogeochemical Properties after Plant Harvest}

Growing vegetables resulted in a drawdown of soil labile N, indicative of plant uptake. This was particularly evident in soils planted to radish, which exhibited significant decreases in INN and DON uniformly across all treatments. In amended treatments, INN concentrations declined by 25-33 times compared to soils in Lab Inc and only three times in UNAM. Similarly, soil DON declined six times in BIOC and INF and 10 times in COMP compared to Lab Inc. Less of a difference was observed in soils planted to lettuce, where the overall INN and DON concentrations remained much greater compared with soils planted to radish. Greater concentrations in lettuce compared to radish could suggest soil labile $\mathrm{N}$ accumulation in excess of plant demand or possible plant stunting (inability to take up N) caused by other growing conditions unrelated to $\mathrm{N}$, including exposure to $\mathrm{Pb}$ or nutrient deficiency.

Growing plants also decreased soil DOC concentrations in almost all treatments except for radish in INF and lettuce in COMP. The declines may be associated with heterotrophic rhizosphere microorganisms, which are typically supported by the carbon rich environment created through root exudates [93]. The symbiotic relationship between plants and rhizosphere microbes often facilitates microbially-mediated processes of soil OM immobilization and mineralization [94]. The lack of a decline in DOC in COMP planted to lettuce points to the sustained presence of OM from compost. This contrasts with INF planted to radish, where the lack of significant change in DOC could reflect an increase in root exudation in the acquisition of nutrients other than $\mathrm{N}$.

\subsubsection{Soil Phosphorus and Iron after Plant Harvest}

In general, soils experienced small increases in available P concentrations, which was especially evident across all treatments in soils in which radish was grown. This could have been associated with greater root biomass relative to lettuce, and hence production of root exudates that fueled rhizosphere microorganisms in support of $\mathrm{P}$ mobilization and mineralization, particularly in COMP. Further, root exudates in the form of organic acids like DOC can electrostatically repel phosphates, thereby increasing P availability in soil [95]. These responses appeared to be suppressed in BIOC, where soil available $\mathrm{P}$ was much lower relative to lab incubated, BIOC-treated soil. This could point to biochar-induced plant $\mathrm{P}$ deficiency. A study on P sorption from biochar produced from the fast pyrolysis of corn stover (Zea mays L.), Ponderosa pine (Pinus ponderosa Lawson and C. Lawson) wood residue, and switchgrass (Panicum virgatum L.) found that corn stover sorped $79 \%$ of bicarbonateextractable $\mathrm{P}$, while switchgrass biochar sorbed $76 \%$, and Ponderosa pine wood biochar sorbed $31 \%$ [96]. The authors speculated that $\mathrm{P}$ sorption by biochar occurs mainly due to the exchange between anions of $P$ in solution with the oxygenated functional groups on surface of biochar. Hence, some portion of P mobilized through root exudate may be readily sorbed. The effect of radish and lettuce on available Fe in soil was nominal, though the greater average concentrations in UNAM planted to radish can be probably explained by reduced plant uptake, which corresponds with less root biomass production in radishes grown in unamended soil. 


\subsection{Soil Lead}

\subsubsection{Soil Lead Concentrations in Absence of Plant Growth}

Amending soils with biochar and compost had no effect on $\mathrm{Pb}$ availability at the beginning of the experiment, which was unexpected. Although their influence can vary based on factors like application rate, source materials, and soil type, both are generally known for their capacity to immobilize soil contaminants [37,43,52]. Organic matter interacts with heavy metal ions in soil through three key mechanisms: sorption to surfaces; precipitation with organic acids and other elements; and complexation with precipitates $[7,43,90,97]$. Biochar's effectiveness in reducing available heavy metals is often attributed to its large surface area, highly microporous structure, and active organic functional groups, in addition to generally high $\mathrm{pH}$ and CEC [37]. Further, biochar contains (hydr)oxides and carbonate phases that cause heavy metals to precipitate [98]. In contrast, compost is more easily decomposable and contains a greater proportion of humic substances, which are responsible for many chemical reactions in soil due to their ability to complex with metal ions, minerals, and hydro(oxides) [8,19,49].

The significant increase in soil $\mathrm{pH}$ brought about by the addition of biochar was also expected to correspond more closely with decreased $\mathrm{Pb}$ availability. In their meta-analysis on the effects of biochar on metal availability, Chen et al. (2018) noted that increases in soil $\mathrm{pH}$ cause metal precipitation, decrease metal availability, and promote adsorption onto soil because of increases in $\mathrm{pH}$-dependent negative charges [43]. Our research did suggest a weak negative correlation with $\mathrm{pH}$ in general across all treatments, however the difference in $\mathrm{pH}$ between BIOC and the other treatments did not appear to affect significant differences in $\mathrm{Pb}$ availability. It is likely that the magnitude of that effect in terms of immobilization would have been more pronounced in an acidic soil than the native alkaline soil used for this experiment [99].

Soil available $\mathrm{Pb}$ was probably influenced more directly by native soil properties than the amendments. Calcareous soil is high in $\mathrm{CaCO}_{3}$ and the alkaline $\mathrm{pH}$ coupled with carbonate buffering can result in the formation of metal-carbonate precipitate complexes that decrease metal availability [100]. Further, Fe and $\mathrm{Pb}$ behave similarly in soils due to commonalities in electronegativity and covalent index (thus the strong correlation observed in this study), and $\mathrm{Pb}$ is also known to form complexes with Fe hydro(oxides), particularly in high $\mathrm{pH}$ soils [101]. This may explain some of the reductions seen in both $\mathrm{Pb}$ and $\mathrm{Fe}$ over time.

\subsubsection{Soil Lead Concentrations after Plant Harvest}

Results showed that the effects of the amendments on $\mathrm{Pb}$ availability in soil are modulated by interactions with plants. The negative correlation between available $\mathrm{Pb}$ and $\mathrm{DOC}$ in BIOC planted to radish suggests that a significant portion of $\mathrm{Pb}$ was effectively chelated by the DOC present and sorbed, reducing its availability in soil. Conversely, radish and lettuce grown in INF mobilized significantly more available $\mathrm{Pb}$ in soil than their respective species in other treatments. Although the inorganic fertilizer used did contain about $4.15 \mathrm{mg} \mathrm{kg}^{-1}$ of added $\mathrm{Pb}$ [102], this concentration was not sufficient to explain the differences. Despite ample N in INF, many soil nutrient deficiencies are known to trigger secretion of root exudates as nutrient chelates, which can also increase the availability of heavy metals [103]. High concentrations of $\mathrm{N}$ likely prompted improved plant growth in INF relative to UNAM, perhaps further increasing the plants' ability to mobilize nutrients, along with available $\mathrm{Pb}$, compared to the control.

Research suggests that greater application rates of compost may improve outcomes in terms of reducing plant $\mathrm{Pb}$ uptake. While it is possible that similar releases of available $\mathrm{Pb}$ occurred in BIOC and COMP, our data suggest the OM buffered them through sorption and chemical processes. Further, fertilizers containing ammonium have also been shown to increase soil acidity [104], which may also have contributed to greater overall concentrations of available $\mathrm{Pb}$ in INF, as it had the lowest $\mathrm{pH}$ among all treatments at the end of the experiment. 


\subsubsection{Lead Uptake in Radish}

The three amendments produced statistically similar $\mathrm{Pb}$ tissue content $\left(\mathrm{mg} \mathrm{kg}^{-1}\right)$ in radish relative to the unamended control. However, $\mathrm{Pb}$ mass load may be a more useful metric for most home gardeners, as it quantifies $\mathrm{Pb}$ on a per plant basis. Guidance from the U.S. Food and Drug Administration on maximum daily intake is also provided on a $\mu \mathrm{g} /$ day basis, specifying a maximum intake of $3 \mu \mathrm{g}$ per day for children and $12.5 \mu \mathrm{g}$ for adults [105]. While $\mathrm{Pb}$ content in radishes grown in COMP was, on average, lower than in INF, average biomass was greater in COMP, hence total plant uptake was nearly identical for both. Similarly, average $\mathrm{Pb}$ content in radishes grown in BIOC was lower than in UNAM, but the radishes had comparable mass loads due to greater biomass production in BIOC.

These results suggest that the amendments can have an undesired effect by increasing plant $\mathrm{Pb}$ uptake, which is likely attributable to the improved plant growth that often accompanies the incorporation of humic substances [49], along with nutrients in general into low-fertility soils. For instance, in a study on the effects of green waste compost, wheat straw biochar, and a combination thereof applied at $5 \%$ and $10 \%(v / w)$ and planted to five leafy greens, Medyńska-Juraszek et al. (2020) found that application of compost alone increased the accumulation of $\mathrm{Cu}, \mathrm{Pb}, \mathrm{Cd}$, and $\mathrm{Cr}$, in Spinacia oleracea $\mathrm{L}$. (spinach) and Anethum graveolens L. (dill) [52]. The study also found that application of biochar often reduced the content of trace elements in tissues, which we observed as well with respect to a modest $(22 \%)$ difference between the tissue content $\left(\mathrm{mg} \mathrm{kg}^{-1}\right)$ of radishes grown in BIOC versus UNAM, although the difference was not statistically significant. MedyńskaJuraszek et al. (2020) noted that the most effective amendment was a combination of biochar and compost at $10 \%(v / w)$ each, which reduced both $\mathrm{Pb}$ and $\mathrm{Cd}$ uptake in nearly all tested plant species, with reductions of $\mathrm{Pb}$ in spinach, dill, and lettuce by $42 \%, 44 \%$, ad $57 \%$, respectively.

The BCFs suggest that radishes grown in BIOC are significantly less likely than those in COMP and INF to take up $\mathrm{Pb}$ relative to exposure. This finding is unsurprising given the tissue mass load findings. Medyńska-Juraszek et al. (2020) observed a similar trend with plants grown in compost displaying a greater BCF (also referred to "bioaccumulation factor," or "BAC") than those grown in biochar. The authors noted that application of organic amendments at high rates $(10 \%)$ decreased the $\mathrm{BCF}$ of the metals they tested in comparison to the control [52].

It is interesting to consider radish $\mathrm{BCF}$ and mass load in combination with soil available $\mathrm{Pb}$ at the end of the experiment (Figure 9c). Although biomass production in BIOC was similar to COMP and INF, radishes grown in BIOC took up significantly less $\mathrm{Pb}$. This suggests that the lower BCF and related mass load were a result of successful immobilization of soil available $\mathrm{Pb}$ over the course of the experiment, which prevented radish uptake. Compost had a similar BCF to both UNAM and INF, but significantly greater mass load than UNAM in combination with significantly less soil available $\mathrm{Pb}$ than both UNAM and INF. Although the addition of compost resulted in increased Pb uptake, the reduction in soil available $\mathrm{Pb}$ through plant uptake was sustained over the course of the experiment. This suggests that compost could be an effective amendment in combination with soil phytoremediation efforts. In contrast, radishes grown in INF had a significantly greater mass load than UNAM and BIOC in addition to greater soil available $\mathrm{Pb}$ than all other treatments at the end of the experiment, indicating that despite high plant uptake, the inorganic fertilizer used also continued to contribute to soil $\mathrm{Pb}$ availability.

For most plant species, the majority of $\mathrm{Pb}$ accumulates in the roots [9], as was observed in this study. This may be an important factor for gardeners in determining which crops to grow in potentially $\mathrm{Pb}$ contaminated soil or in managing safe daily consumption levels of home-grown vegetables. Radishes grown in COMP demonstrated the greatest capacity for $\mathrm{Pb}$ translocation to shoots, followed by BIOC. Translocation is influenced by many factors, including species, physiological factors, and characteristics of individual metals, and is also known to increase in the presence of organic chelators like EDTA and DTPA $[9,53]$. In a 
study on $\mathrm{Pb}$ uptake by Brassica campestris L., (pak choi cabbage) after treatment with green waste compost applied at 2\%,5\%, and 10\% (w/w), Liu et al. (2020) suggest that humic and fulvic acids decomposed from compost played a role as chelators to form $\mathrm{Pb}$ complexes, which influenced translocation in tissues. Our data seem to support these findings [53]. High $\mathrm{Pb}$ concentrations are also known to destroy the physical barrier formed by the Casparian strip [9].

Low chlorophyll concentrations in plants grown in BIOC were likely not directly linked to $\mathrm{Pb}$ uptake given the low tissue $\mathrm{Pb}$ status relative to COMP and INF, but could point to the early onset of $\mathrm{N}$ deficiency. Radish and lettuce samples both displayed symptoms often associated with $\mathrm{Pb}$ exposure, which included severe stunting, chlorosis, poor root development, and lowered rates of germination. However, it was not possible to discern whether the observations we observed, such as stunting, were caused by $\mathrm{Pb}$ exposure or a nutrient deficiency, which can be expressed similarly. High concentrations of heavy metals can also amplify existent nutrient deficiencies in calcareous soils by interfering with plant nutrient uptake and transportation. For example, $\mathrm{Pb}$ has been shown to reduce $\mathrm{Fe}^{2+}$ concentrations in radish leaves [24]. Further, the soil used in the study was known to be contaminated with multiple contaminants [unpublished data], which also limited our ability to specifically attribute visual symptoms of toxicity to $\mathrm{Pb}$. This highlights the difficulty many gardeners may encounter in discerning the difference, and underscores the need for soil testing in potentially contaminated sites.

\subsection{Limitations and Future Opportunities}

An overarching goal of this experiment was to provide information and recommendations for small-scale urban gardeners on effective, affordable options to reduce potential exposure to $\mathrm{Pb}$ through consumption of contaminated crops. Our results suggest that a combination of biochar and compost is a promising approach for achieving desired crop production combined with reduced plant $\mathrm{Pb}$ uptake. Awareness and use of locally-sourced compost is commonplace; however, despite its accessibility in most parts of the U.S., use of biochar is not widespread among gardeners. The lack of broad adoption may be partly attributed to many producers in the U.S. having only small to medium-scale production and marketing capacity. At the same time, the promotion of biochar among small-scale urban gardeners as a cost-effective and environmentally sustainable solution is also predicated on the use of locally-available resources, suggesting a need for additional producers at the local level. Secondary to general awareness and wide-spread adoption of biochar, many consumers are likely unfamiliar with how factors like feedstock and pyrolysis process can influence desired soil outcomes. Compost can be produced at home and is frequently available free of cost through city municipalities. In contrast, the average retail price of biochar is around $\$ 3.08 / \mathrm{kg}$ in the U.S. [106], presenting another limitation for some urban gardeners. Nonetheless, the biochar industry shows promise. A recent analysis valued the U.S. biochar sales in 2019 at $\$ 97.8$ million [107], suggesting a growing market exists among gardeners as demand for organic and sustainable products increases.

Future research would be benefited by field studies, as a majority of data on biochar has been collected through laboratory and greenhouse experiments. Additionally, as studies on biochar plus compost mixes are becoming more popular, further research on optimal application ratios for reduction of soil $\mathrm{Pb}$ and other contaminants should be explored. Another promising area of study in the combination of biochar and compost pertains to timing of applications, namely whether best results are achieved through mixing at the time of soil amendment or if sequential applications are more beneficial (e.g., addition of biochar followed by compost after pre-incubation period or mixture of biochar with feedstock prior to composting).

\section{Conclusions}

In general, amendments selected for this experiment and incubated in absence of plants do not impact soil available $\mathrm{Pb}$. However, amended soils planted to food crops 
respond differently, not only in terms of soil available $\mathrm{Pb}$, but also in regard to differences in plant uptake. Amending potentially contaminated garden soils with biochar appears to be a reliable method to reduce the risk of $\mathrm{Pb}$ exposure among urban gardeners. Significant declines in both soil $\mathrm{Pb}$ availability and plant bioaccumulation (almost $20 \%$ and $11 \%$, respectively) in native soils amended with biochar point to effective $\mathrm{Pb}$ immobilization and reduced uptake by plants. Not as effective as biochar, compost nonetheless reduces soil available $\mathrm{Pb}$ by $8 \%$ when planted to radish, although this may primarily be a reflection of removal through plant uptake. The observed 19\% increase in tissue content of radish grown in soil amended with compost is of concern, however, particularly for those growing root crops. In contrast, the water-soluble inorganic fertilizer used in this study has a detrimental impact in all respects. Not only does it mobilize soil $\mathrm{Pb}$ by $11 \%$, but it also enhances plant uptake and bioaccumulation in radish by as much as $40 \%$. This is likely due to a lack of key chemical reactions (adsorption, complexation, and precipitation) largely associated with the presence of organic matter that are known to reduce soil $\mathrm{Pb}$ availability. Further, because the added nutrients are in an exclusively plant-available form, plants grown in soil treated with an inorganic fertilizer produce significantly greater biomass than those in an unamended soil, increasing the amount of $\mathrm{Pb}$ deposited in plant tissues on a per plant basis. For these reasons, use of water-soluble inorganic fertilizer should be avoided in potentially $\mathrm{Pb}$ contaminated garden soils, especially those low in organic matter. Gardeners are encouraged to test their soils for contamination and carefully consider crop selection, avoiding root crops. When needed, they should apply biochar in combination with compost. This combination of treatments is recommended to overcome a potential for initial $\mathrm{N}$ deficiency induced by biochar, which is alleviated by compost. More information on remediation of garden contaminated soils should be broadly available to audiences interested converting open urban areas into garden spaces.

Author Contributions: Conceptualization, U.N.; methodology, T.G. and U.N.; software, T.G. and U.N.; validation, T.G. and U.N.; formal analysis, T.G.; investigation, T.G.; resources, U.N.; data curation, T.G.; writing-original draft preparation, T.G. and U.N.; writing-review and editing, T.G. and U.N.; visualization, T.G. and U.N.; supervision, U.N.; project administration, U.N.; funding acquisition, U.N. All authors have read and agreed to the published version of the manuscript.

Funding: This research was funded by Hatch Multistate Research Fund (Grant No. 10047928) and the University of Wyoming, Department of Plant Sciences.

Institutional Review Board Statement: Not applicable.

Informed Consent Statement: Not applicable.

Data Availability Statement: The data presented in this study are openly available in FigShare at doi:10.6084/m9.figshare.14703483.

Acknowledgments: The authors would like to thank the Wyoming State Geological Survey, the Colorado State University Soil, Water, and Plant Testing Lab, and Ward Laboratories, Inc. of Kearney, NE, USA for the use of lab instruments and technical support. The authors would also like to thank the anonymous peer reviewers for their valuable input on the final document.

Conflicts of Interest: The authors declare no conflict of interest. The funders had no role in the design of the study; in the collection, analyses, or interpretation of data; in the writing of the manuscript, or in the decision to publish the results.

\section{References}

1. Armstrong, D. A survey of community gardens in upstate New York: Implications for health promotion and community development. Health Place 2000, 6, 319-327. [CrossRef]

2. Twiss, J.; Dickinson, J.; Duma, S.; Kleinman, T.; Paulsen, H.; Rilveria, L. Community Gardens: Lessons Learned from California Healthy Cities and Communities. Am. J. Public Health 2003, 93, 1435-1438. [CrossRef]

3. Brown, K.H.; Jameton, A.L. Public Health Implications of Urban Agriculture. J. Public Health Policy 2000, 21, 20-39. [CrossRef]

4. Coelho, F.; Coelho, E.; Egerer, M. Local food: Benefits and failings due to modern agriculture. Sci. Agric. 2018, 75, 84-94. [CrossRef] 
5. Berg, A.E.; Winsum-Westra, M.V.; Vries, S.D.; Dillen, S.M. Allotment gardening and health: A comparative survey among allotment gardeners and their neighbors without an allotment. Environ. Health A Glob. Access Sci. Source 2010, 9, 1-12. [CrossRef]

6. Blair, D.; Giesecke, C.C.; Sherman, S. A dietary, social and economic evaluation of the Philadelphia urban gardening project. J. Nutr. Educ. 1991, 23, 161-167. [CrossRef]

7. Lwin, C.S.; Seo, B.H.; Kim, H.U.; Owens, G.; Kim, K.R. Application of soil amendments to contaminated soils for heavy metal immobilization and improved soil quality-A critical review. Soil Sci. Plant Nutr. 2018, 156-167. [CrossRef]

8. Zaccone, C.; Caterina, R.D.; Rotunno, T.; Quinto, M. Soil-Farming System-Food-Health: Effect of conventional and organic fertilizers on heavy metal $(\mathrm{Cd}, \mathrm{Cr}, \mathrm{Cu}, \mathrm{Ni}, \mathrm{Pb}, \mathrm{Zn})$ content in semolina samples. Soil Tillage Res. 2010, 107, 97-105. [CrossRef]

9. Pourrut, B.; Shahid, M.; Dumat, C.; Winterton, P.; Pinelli, E. Lead uptake, toxicity, and detoxification in plants. Rev. Environ. Contam. Toxicol. 2011, 113-136. [CrossRef]

10. Angelone, M.; Bini, C. Trace elements concentrations in soils and plants of western Europe. In Biogeochemistry of Trace Metals, 1st ed.; Adriano, D.C., Ed.; Lewis Publishers: Boca Raton, FL, USA, 1992; pp. 19-60.

11. Atafar, Z.; Mesdaghinia, A.; Nouri, J.; Homaee, M.; Yunesian, M.; Ahmadimoghaddam, M.; Mahvi, A.H. Effect of fertilizer application on soil heavy metal concentration. Environ. Monit. Assess. 2008, 160, 83-89. [CrossRef] [PubMed]

12. Liu, X.; Zhang, A.; Ji, C.; Joseph, S.D.; Bian, R.; Li, L.; Pan, G.; Paz-Ferreiro, J. Biochar's effect on crop productivity and the dependence on experimental conditions-A meta- analysis of literature data. Plant Soil 2013, 373, 583-594. [CrossRef]

13. Meuser, H. Causes of soil contamination in the urban environment. In Contaminated Urban Soils, 1st ed.; Alloway, B., Trevors, T.J., Eds.; Springer: Heidelberg, Germany, 2010; Volume 18, pp. 29-94.

14. Wei, B.; Yang, L. A review of heavy metal contaminations in urban soils, urban road dusts and agricultural soils from China. Microchem. J. 2010, 94, 99-107. [CrossRef]

15. Kim, B.F.; Poulsen, M.N.; Margulies, J.D.; Dix, K.L.; Palmer, A.M.; Nachman, K.E. Urban Community Gardeners' Knowledge and Perceptions of Soil Contaminant Risks. PLoS ONE 2014, 9, 1-9. [CrossRef] [PubMed]

16. Harms, A.M.; Presley, D.R.; Hettiarachchi, G.M.; Thien, S.J. Assessing the Educational Needs of Urban Gardeners and Farmers on the Subject of Soil Contamination. J. Ext. Educ. 2013, 51, 1FEA10.

17. McBride, M.B. Environmental Chemistry of Soils; Oxford University Press: New York, NY, USA, 1994; pp. $308-341$.

18. Pinto, A.; Mota, A.; Varennes, A.D.; Pinto, F. Influence of organic matter on the uptake of cadmium, zinc, copper and iron by sorghum plants. Sci. Total Environ. 2004, 326, 239-247. [CrossRef]

19. Antoniadis, V.; Levizoua, E.; Shaheen, S.M.; Ok, Y.S.; Sebastian, A.; Baume, C.; Prasad, M.N.V.; Rinklebeg, J. Trace elements in the soil-plant interface: Phytoavailability, translocation, and phytoremediation-A review. Earth-Sci. Rev. 2017, 171, 221-245. [CrossRef]

20. Huang, Y.; Chen, Q.; Deng, M.; Japenga, J.; Li, T.; Yang, X.; He, Z. Heavy metal pollution and health risk assessment of agricultural soils in a typical peri-urban area in southeast China. J. Environ. Manag. 2018, 207, 159-168. [CrossRef]

21. Al-Heety, E.A.M.S.; Yassin, K.H.; Abd-Alsalaam, S. Health risk assessment of some heavy metals in urban community garden soils of Baghdad City, Iraq. Hum. Ecol. Risk Assess. 2017, 23, 225-240. [CrossRef]

22. Khan, D.; Frankland, B. Effects of cadmium and lead on radish plants with particular reference to movement of metals through soil profile and plant. Plant Soil 1983, 70, 335-345. [CrossRef]

23. Abadin, H.; Ashizawa, A.; Stevens, Y.-W.; Llados, F.; Diamond, G.; Sage, G.; Swarts, S.G. Toxicological Profile for Lead. U.S. Department of Health and Human Services. Available online: https://www.atsdr.cdc.gov/toxprofiles/tp13.pdf (accessed on 21 June 2021).

24. Gopal, R.; Botany, A.H. Excess lead alters growth, metabolism and translocation of certain nutrients in radish. Chemosphere 2008, 70, 1539-1544. [CrossRef]

25. Saxena, G.; Purchase, D.; Mulla, S.I.; Saratale, G.D.; Bharagava, R.N. Phytoremediation of Heavy Metal-Contaminated Sites: Eco-environmental Concerns, Field Studies, Sustainability Issues, and Future Prospects. Rev. Environ. Contam. Toxicol. 2019, 249. [CrossRef]

26. Kizilkaya, R.; Akin, T.; Bayrakli, B.; Sălam, M. Microbiological characteristics of soils contaminated with heavy metals. Eur. J. Soil Biol. 2004, 40, 95-102. [CrossRef]

27. Ussiri, D.A.; Lal, R. Carbon sequestration in reclaimed mine soils. CRC Crit. Rev. Plant Sci. 2005, 24, 151-165. [CrossRef]

28. Walker, D.; Clemente, R.; Roig, A.; Bernal, M. The effects of soil amendments on heavy metal bioavailability in two contaminated Mediterranean soils. Environ. Pollut. 2003, 122, 303-312. [CrossRef]

29. Clemente, R.; Paredes, C.; Bernal, M. A field experiment investigating the effects of olive husk and cow manure on heavy metal availability in a contaminated calcareous soil from Murcia (Spain). Agric. Ecosyst. Environ. 2007, 118, 319-326. [CrossRef]

30. García-Gil, J.; Ceppi, S.; Velasco, M.; Polo, A.; Senesi, N. Long-term effects of amendment with municipal solid waste compost on the elemental and acidic functional group composition and pH-buffer capacity of soil humic acids. Geoderma 2004, 121, 135-142. [CrossRef]

31. Vega, F.; Andrade, M.; Covelo, E. Influence of soil properties on the sorption and retention of cadmium, copper and lead, separately and together, by 20 soil horizons: Comparison of linear regression and tree regression analyses. J. Hazard. Mater. 2010, 174, 522-533. [CrossRef] 
32. Dahn, R.; Scheidegger, A.; Manceau, A.; Schlegel, M.; Baeyens, B.; Bradbury, M.; Chateigner, D. Structural evidence for the sorption of $\mathrm{Ni}(\mathrm{II})$ atoms on the edges of montmorillonite clay minerals: A polarized X-ray absorption fine structure study. Geochim. Cosmochim. Acta 2003, 67, 1-15. [CrossRef]

33. Bi, X.; Ren, L.; Gong, M.; He, Y.; Wang, L.; Ma, Z. Transfer of cadmium and lead from soil to mangoes in an uncontaminated area, Hainan Island, China. Geoderma 2010, 155, 115-120. [CrossRef]

34. Dumat, C.; Quenea, K.; Bermond, A.; Toinen, S.; Benedetti, M. Study of the trace metal ion influence on the turnover of soil organic matter in cultivated contaminated soils. Environ. Pollut. 2006, 142, 521-529. [CrossRef]

35. Uzu, G.; Sobanska, S.; Aliouane, Y.; Pradere, P.; Dumat, C. Study of lead phytoavailability for atmospheric industrial micronic and sub-micronic particles in relation with lead speciation. Environ. Pollut. 2009, 157, 1178-1185. [CrossRef]

36. Violante, A.; Cozzolino, V.; Perelomov, L.; Caporale, A.; Pigna, M. Mobility and bioavailability of heavy metals and metalloids in soil environments. Soil Sci. Plant Nutr. 2010, 10, 268-292. [CrossRef]

37. Cheng, J.; Li, Y.; Gao, W.; Chen, Y.; Pan, W.; Lee, X.; Tang, Y. Effects of biochar on Cd and Pb mobility and microbial community composition in a calcareous soil planted with tobacco. Biol. Fertil. Soils 2018, 54, 373-383. [CrossRef]

38. Streubel, J.; Collins, H.; Garcia-Perez, M.; Tarara, J.; Granatstein, D.; Kruger, C. Influence of Contrasting Biochar Types on Five Soils at Increasing Rates of Application. Soil Sci. Soc. Am. J. 2011, 75, 1402-1413. [CrossRef]

39. Lehmann, J.; Gaunt, J.; Rondon, M. Biochar Sequestration in Terrestrial Ecosystems-A Review. Mitig. Adapt. Strateg. Glob. Chang. 2006, 11, 403-427. [CrossRef]

40. Bruun, W.W.; Müller-Stöer, D.; Ambus, P.; Hauggaard-Nielsen, H. Application of biochar to soil and N2o emmisions: Potential effects of blending fast-pyrolysis biochar with anaerobically digested slurry. Eur. J. Soil Sci. 2011, 62, 581-589. [CrossRef]

41. Lehmann, J.; da Silva, J.; Steiner, C.; Nehls, T.; Zech, W.; Glaser, B. Nutrient availability and leaching in an archaeological anthrosol and a ferralsol of the central Amazon Basin: Fertilizer, manure and charcoal amendments. Plant Soil 2003, 249, 343-357. [CrossRef]

42. Bian, R.; Joseph, S.; Cui, L.; Pan, G.; Li, L.; Liu, X.; Zhang, A.; Rutlidge, H.; Wong, S.; Chia, C.; et al. A three-year experiment confirms continuous immobilization of cadmium and lead in contaminated paddy field with biochar amendment. J. Hazard. Mater. 2014, 272, 121-128. [CrossRef]

43. Chen, D.; Liu, X.; Bian, R.; Cheng, K.; Zhang, X.; Zheng, J.; Joseph, S.; Crowley, D.; Pan, G.; Li, L. Effects of biochar on availability and plant uptake of heavy metals-A meta-analysis. J. Environ. Manag. 2018, 222, 76-85. [CrossRef] [PubMed]

44. Lehmann, J. Nature. A handful of carbon. Nature 2007, 447, 143-144. [CrossRef]

45. Ippolito, J.A.; Novak, J.M.; Busscher, W.J.; Ahmedna, M.; Rehrah, D.; Watts, D.W. Switchgrass Biochar Affects Two Aridisols. J. Environ. Qual. 2012, 41, 1123-1130. [CrossRef]

46. Ippolito, J.A.; Cui, L.; Kammann, C.; Wrage-Mönnig, N.; Estavillo, J.M.; Fuertes-Mendizabal, T.; Cayuela, M.L.; Sigua, G.; Novak, J.; Spokas, K.; et al. Feedstock choice, pyrolysis temperature and type influence biochar characteristics: A comprehensive meta-data analysis review. Biochar 2020, 2, 421-438. [CrossRef]

47. Gajanan, S.G.; Shinde, S.K.; Kadam, A.A.; Saratale, R.G.; Saratale, G.D.; Kumar, M.; Palem, R.R.; AL-Shwaiman, H.A.; Elgorban, A.M.; Syed, A.; et al. Review on biomass feedstocks, pyrolysis mechanism and physicochemical properties of biochar: State-ofthe-art framework to speed up vision of circular bioeconomy. J. Clean. Prod. 2021, 297, 126645. [CrossRef]

48. Pennanen, T.; Srivastava, V.; Sillanpaa, M.; Sainio, T. Compost: Potent biosorbent for the removal of heavy metals from industrial and landfill stormwater. J. Clean. Prod. 2020, 273, 122736. [CrossRef]

49. Trevisan, S.; Francioso, O.; Quaggiotti, S.; Nardi, S. Humic substances biological activity at the plant-soil interface. Plant Signal. Behav. 2010, 5, 635-643. [CrossRef]

50. Haroon, B.; Irshad, M.; Hafeez, F.; Pervez, A. Fractionation of heavy metals in contaminated soil after amendment with composted cow manure and poultry litter. Arab. J. Geosci. 2019, 12. [CrossRef]

51. Karimi, A.; Moezzi, A.; Chorom, M.; Enayatizamir, N. Application of Biochar Changed the Status of Nutrients and Biological Activity in a Calcareous Soil. Soil Sci. Plant Nutr. 2020, 20, 450-459. [CrossRef]

52. Medyńska-Juraszek, A.; Bednik, M.; Chohura, P. Assessing the Influence of Compost and Biochar Amendments on the Mobility and Uptake of Heavy Metals by Green Leafy Vegetables. Int. J. Environ. Res. Public Health 2020, 17, 7861. [CrossRef] [PubMed]

53. Liu, Y.; Sun, X.; Li, S.; Zhou, W.; Ma, Q.; Zhang, J. Influence of green waste compost on Pb-polluted soil remediation, soil quality improvement, and uptake by Pakchoi cabbage (Brassica campestris L. ssp). Environ. Sci. Pollut. Res. 2020, 27, 7693-7701. [CrossRef]

54. Sun, L.; Niu, Z.; Sun, T. Effects of amendments of N, P, Fe on phytoextraction of Cd, Pb, Cu, and Zn in soil of Zhangshi by mustard, cabbage, and sugar beet. Environ. Toxicol. 2007, 22, 565-571. [CrossRef]

55. Lin, C.; Zhu, T.; Liu, L.; Wanga, D. Influences of major nutrient elements on Pb accumulation of two crops from a Pb-contaminated soil. J. Hazard. Mat. 2010, 174, 202-208. [CrossRef] [PubMed]

56. Singh, A.; Agrawala, M.; Marshall, F.M. The role of organic vs. inorganic fertilizers in reducing phytoavailability of heavy metals in a wastewater-irrigated area. Ecol. Eng. 2010, 36, 1733-1740. [CrossRef]

57. He, W.; Yang, X.; Yang, J.; He, Z. Effect of lead on plant availability of phosphorus and potassium in a vegetable-soil system. Environ. Sci. Pollut. Res. 2018, 25, 34793-34797. [CrossRef] [PubMed]

58. United States Census Bureau. 2010. Available online: https://www.census.gov/quickfacts/fact/table/laramiecitywyoming/ POP060210 (accessed on 1 April 2021).

59. 2017 Census of Agriculture, County Profile. USDA National Agricultural Statistics Service. Available online: https://www.nass.usda. gov/Publications/AgCensus/2017/Online_Resources/County_Profiles/Wyoming/cp56001.pdf (accessed on 10 June 2021). 
60. Western Regional Climate Center. Laramie AP, Wyoming. Available online: https://wrcc.dri.edu/cgi-bin/cliMAIN.pl?wy5415 (accessed on 25 May 2021).

61. U.S. Department of Agriculture, Natural Resources Conservation Service. ALCOVA Series. 2001. Available online: https: / / soilseries.sc.egov.usda.gov/OSD_Docs/A/ALCOVA.html (accessed on 25 May 2021).

62. Knight, J. An Eyesore? The U.S. Might Have Needed It-Laramie's Aluminum Plant a WWII Reminder. Albany County Historical Society. 2019. Available online: https:/ / www.wyoachs.com/larmies-living-history-businesses/2019/3/23/an-eyesore-the-usmight-have-needed-it-laramies-aluminum-plant-a-wwii-reminder (accessed on 25 May 2021).

63. Tippin, C. DEQ Overseeing Cleanup of Site South of Laramie. Laramie Boomerang. 2017. Available online: https: //www.laramieboomerang.com/news/deq-overseeing-cleanup-of-site-south-of-laramie/article_be2471d4-f9c9-593f-8521-f6 89bb215f45.html (accessed on 25 May 2021).

64. Bremner, J. Nitrogen Total. In Methods of Soil Analysis Part 3: Chemical Methods; Sparks, D., Ed.; Soil Science Society of America: Madison, WI, USA, 1996; pp. 1085-1122.

65. Doane, T.; Horwath, W. Spectrophotometric determination of nitrate with a single reagent. Anal. Lett. 2003, 39, 2713-2722. [CrossRef]

66. Hart, S.; Stark, J.M.; Davidson, E. Nitrogen mineralization, immobilization, and nitrification. In Methods of Soil Analysis. Part 2: Microbiological and Biochemical Properties, 5.2; Weaver, R.W., Angle, S., Bottomly, P., Eds.; Soil Science Society of America: Madison, WI, USA, 1994; pp. 985-1018.

67. Newcomb, J.; Carrilo, Y. Shimadzu Carbon and Nitrogen Analyzer Protocol; University of Wyoming: Laramie, WY, USA, 2011; unpublished work.

68. Sherrod, L.A.; Dunn, G.; Peterson, G.A.; Kolberg, R.L. Inorganic carbon analysis by modified pressure-calcimeter method. Soil Sci. Soc. Am. J. 2002, 66, 299-305. [CrossRef]

69. Olsen, S.; Cole, C.V.; Watanabe, F.S.; Dean, L.A. Estimation of Available Phosphorus in Soils by Extraction with Sodium Bicarbonate. In United States Department of Agriculture Circular No. 939; United States Department of Agriculture: Washington, DC, USA, 1954.

70. Lindsay, W.; Norvell, W. Development of a DTPA soil test for zinc, iron, manganese, and copper. Soil Sci. Soc. Am. 1978, 42, 421-428. [CrossRef]

71. Soon, Y.K. Determination of Cadmium, Chromium, Cobalt, Lead and Nickel in Plant Tissue. In Handbook of Reference Methods for Plant Analysis, 1st ed.; Kalra, Y.P., Ed.; CRC Press: Boca Raton, FL, USA, 1998; pp. 193-198.

72. Antonangeli, J.A.; Zhang, H. The Use of Biochar as a Soil Amendment to Reduce Potentially Toxic Metals (PTMs) Phytoavailability In Applications of Biochar for Environmental Safety; Abdelhafez, A.A., Abbas, M.H., Eds.; Intechopen: London, UK, 2020. [CrossRef]

73. Ahmad, M.; Usman, A.R.; Al-Faraj, A.S.; Ahmad, M.; Sallam, A.; Al-Wabel, M.I. Phosphorus-loaded biochar changes soil heavy metals availability and uptake potential of maize (Zea mays L.) plants. Chemosphere 2018, 194, 327-339. [CrossRef]

74. Self, J. Soil Test Explanation-0.502. Colorado State University Extension. 2010. Available online: https://extension.colostate edu/topic-areas/agriculture/soil-test-explanation-0-502/ (accessed on 25 May 2021).

75. Swift, C. Vegetable Gardening-Nitrogen Recommendations-7.247. Colorado State University Extension. 2020. Available online: https:/ / extension.colostate.edu/topic-areas/yard-garden/vegetable-gardening-nitrogen-recommendations-7-247/ (accessed on 25 May 2021).

76. Awan, S.; Ippolito, J.A.; Ullman, J.L.; Ansari, K.; Cui, L.; Siyal, A.A. Biochars reduce irrigation water sodium adsorption ratio. Biochar 2021, 3, 77-87. [CrossRef]

77. Ding, X.; Jiang, Y.; Zhao, H.; Guo, D.; He, L.; Liu, F.; Zhou, Q.; Nandwani, D.; Hui, D.; Yu, J. Electrical conductivity of nutrient solution influenced photosynthesis, quality, and antioxidant enzyme activity of pakchoi (Brassica campestris L. ssp. Chinensis) in a hydroponic system. PLoS ONE 2018, 13. [CrossRef]

78. Zhang, X.; Zhao, Y.; Zhu, L.; Cui, H.; Jia, L.; Xie, X.; Li, J.; Wei, Z. Assessing the use of composts from multiple sources based on the characteristics of carbon mineralization in soil. Waste Manag. 2017, 70, 30-36. [CrossRef]

79. Tambone, F.; Genevini, P.; Adani, F. The Effects of Short-Term Compost Application On Soil Chemical Properties and on Nutritional Status of Maize Plant. Compost. Sci. Util. 2007, 15, 176-183. [CrossRef]

80. Whalen, J.K.; Benslim, H.; Jiao, Y.; Sey, B.K. Soil organic carbon and nitrogen pools as affected by compost applications to a sandy-loam soil in Québec. Can. J. Soil Sci. 2008, 88, 443-450. [CrossRef]

81. Yang, X.; Reynolds, W.D.; Drury, C.F.; Fleming, R.; Tan, C.S.; Denholm, K.; Yang, J. Organic carbon and nitrogen stocks in a clay loam soil 10 years after a single compost application. Can. J. Soil Sci. 2014, 94, 357-363. [CrossRef]

82. Kameyama, K.; Miyamoto, T.; Shiono, T.; Shinogi, Y. Influence of Sugarcane Bagasse-derived Biochar Application on Nitrate Leaching in Calcaric Dark Red Soil. J. Environ. Qual. 2012, 41, 1131-1137. [CrossRef]

83. Nguyen, T.T.; Xu, C.Y.; Tahmasbian, I.; Che, R.; Xu, Z.; Zhou, X.; Wallace, H.M.; Bai, S.H. Effects of biochar on soil available inorganic nitrogen: A review and meta-analysis. Geoderma 2017, 288, 79-96. [CrossRef]

84. Singh, B.; Cowie, A.; Smernik, R. Biochar carbon stability in a clayey soil as a function of feedstock and pyrolysis temperature. Environ. Sci. Technol. 2012, 46, 11770-11778. [CrossRef]

85. Fiorentinoa, N.; Sánchez-Monedero, M.; Lehmann, J.; Enders, A.; Fagnano, M.; Cayuelab, M. Interactive priming of soil N transformations from combining biochar and urea inputs: A $15 \mathrm{~N}$ isotope tracer study. Soil Biol. Biochem. 2019, 131, 166-175. [CrossRef] 
86. United Nations Food and Agriculture Organization (FAO). Management of Calcareous Soils. Available online: http://www.fao. org/soils-portal/soil-management/management-of-some-problem-soils/calcareous-soils/en/\#: \{\}:text=Phosphorous\%20is\% 20often\%20lacking\%20in,be\%20in\%20water\%20soluble\%20form (accessed on 25 May 2021).

87. Havlin, J.L.; Tisdale, S.L.; Nelson, W.L.; Beaton, J.D. Soil Fertility and Fertilizers, 8th ed.; Pearson, Inc.: Boston, MA, USA, 2013; pp. 261-269.

88. Prasad, R.; Chakraborty, D. Phosphorus Basics: Understanding Phosphorus Forms and Their Cycling in the Soil. Alabama A\&M and Auburn Universities. Available online: https://www.aces.edu/wp-content/uploads/2019/04/ANR-2535-PhosphorusBasics_041719L.pdf (accessed on 24 May 2021).

89. Weng, L.; Vega, F.A.; Van Riemsdijk, W.H. Competitive and synergistic effects in pH dependent phosphate adsorption in soils: LCD modeling. Environ. Sci. Technol. 2011, 45, 8420-8428. [CrossRef] [PubMed]

90. Mohamed, I.; Ahamadou, B.; Li, M.; Gong, C.; Cai, P.; Liang, W.; Huang, Q. Fractionation of copper and cadmium and their binding with soil organic matter in a contaminated soil amended with organic materials. J. Soils Sediments 2010, 10, 973-982. [CrossRef]

91. Beegle, D.B.; Durst, P.T. Managing Phosphorus for Crop Production. Pennsylvania State University. 2002. Available online: https:/ / extension.psu.edu/programs/nutrient-management/educational/soil-fertility/managing-phosphorus-for-cropproduction/extension_publication_file (accessed on 25 May 2021).

92. Ippolito, J.A.; Stromberger, M.E.; Lentz, R.D.; Dungan, R.S. Hardwood Biochar Influences Calcareous Soil Physicochemical and Microbiological Status. J. Environ. Qual. 2014, 43, 681-689. [CrossRef] [PubMed]

93. Morgan, J.A.; Bending, G.D.; White, P.J. Biological costs and benefits to plant-microbe interactions in the rhizosphere. J. Exp. Bot. 2005, 56, 1729-1739. [CrossRef] [PubMed]

94. Sarfraz, R.; Hussain, A.; Sabir, A.; Fekih, I.B.; Ditta, A.; Xing, S. Role of biochar and plant growth promoting rhizobacteria to enhance soil carbon sequestration-A review. Environ. Monit. Assess. 2019, 191. [CrossRef]

95. Fink, J.R.; Inda, A.V.; Tiecher, T.; Barrón, V. Iron oxides and organic matter on soil phosphorus availability. Cienc. Agrotecnol. 2016, 40, 369-379. [CrossRef]

96. Chintala, R.; Schumacher, T.E.; McDonald, L.M.; Clay, D.E.; Malo, D.D.; Papiernik, S.K.; Clay, S.A.; Julson, J.L. Phosphorus Sorption and Availability from Biochars and Soil/Biochar Mixtures. Clean 2014, 42, 626-634. [CrossRef]

97. Ström, L.; Owen, A.G.; Godbold, D.L.; Jones, D.L. Organic acid behaviour in a calcareous soil implication for rhizosphere nutrient cycling. Soil Biol. Biochem. 2005, 37, 2046-2054. [CrossRef]

98. Ippolito, J.A.; Berry, C.M.; Strawn, D.G.; Novak, J.M.; Levine, J.; Harley, A. Biochars Reduce Mine Land Soil Bioavailable Metals. J. Environ. Qual. 2017, 46, 411-419. [CrossRef] [PubMed]

99. Stewart, C.E.; Zheng, J.; Botte, J.; Cotrufo, M.F. Co-generated fast pyrolysis biochar mitigates greenhouse gas emissions and increases carbon sequestration. Glob. Chang. Biol. Bioenergy 2013, 5, 153-164. [CrossRef]

100. Shahkolaie, S.S.; Baranimotlagh, M.; Dordipour, E.; Khormali, F. Cadmium and lead immobilization in a calcareous contaminated soil using the cost-effective amendments. Arab. J. Geosci. 2019, 12. [CrossRef]

101. Dong, Y.; Ma, L.; Rhue, R. Relation of enhanced Pb solubility to Fe partitioning in soils. Environ. Pollut. 2000, 110, 515-522. [CrossRef]

102. Information Registered Fertilizer, Ag Mineral, Ag Amendment, and Lime Products. Oregon Department of Agriculture. Available online: http:/ / oda.state.or.us/dbs/heavy_metal/detail.lasso?-op=eq\&product_id=2462 (accessed on 18 February 2021).

103. Sherene, T. Effect of Dissolved Organic Carbon (DOC) on Heavy Metal Mobility in Soils. Nat. Environ. Pollut. Technol. 2009, 8, 817-821.

104. Guan, W. Effects of Nitrogen Fertilizers on Soil pH. Purdue University, Vegetable Crops Hotline. 2016. Available online: https://vegcropshotline.org/article/effects-of-nitrogen-fertilizers-on-soil-ph/ (accessed on 25 February 2021).

105. U.S. Food \& Drug Administration. Lead in Food, Foodwares, and Dietary Supplements. 2020. Available online: https: / / www.fda.gov/food/metals-and-your-food/lead-food-foodwares-and-dietary-supplement. (accessed on 25 May 2021 ).

106. State of the Biochar Industry 2014. International Biochar Initiative. Available online: https://biochar-international.org/state-ofthe-biochar-industry-2014/ (accessed on 15 June 2021).

107. Grand View Research. U.S. Biochar Market Size, Share \& Trend Analysis Report by Technology (Gasification, Pyrolysis), By Application (Agriculture, Animal Feed, Health \& Beauty Products), by States, and Segment Forecasts, 2020-2027. Available online: https:/ / www.grandviewresearch.com/industry-analysis/us-biochar-market (accessed on 15 June 2021). 